\title{
Chemical Modifications of Cassava Peel as Adsorbent Material for Metals Ions from Wastewater
}

\author{
Daniel Schwantes, ${ }^{1}$ Affonso Celso Gonçalves Jr., ${ }^{2}$ Gustavo Ferreira Coelho, ${ }^{3}$ \\ Marcelo Angelo Campagnolo, ${ }^{1,2}$ Douglas Cardoso Dragunski, ${ }^{1}$ \\ César Ricardo Teixeira Tarley, ${ }^{4}$ Alisson Junior Miola, ${ }^{2}$ and Eduardo Ariel Völz Leismann ${ }^{2}$ \\ ${ }^{1}$ Pontifical Catholic University of Parana, 85902-532 Toledo, PR, Brazil \\ ${ }^{2}$ State University of Western Parana, 85960-000 Marechal Cândido Rondon, PR, Brazil \\ ${ }^{3}$ Dynamic Union of the Falls Colleges (UDC), 85884-000 Medianeira, PR, Brazil \\ ${ }^{4}$ Londrina State University, 86057-970 Londrina, PR, Brazil
}

Correspondence should be addressed to Daniel Schwantes; daniel.schwantes@pucpr.br

Received 18 February 2016; Accepted 9 May 2016

Academic Editor: Angeles Val Del Rio

Copyright (C) 2016 Daniel Schwantes et al. This is an open access article distributed under the Creative Commons Attribution License, which permits unrestricted use, distribution, and reproduction in any medium, provided the original work is properly cited.

Residues from the processing of cassava roots (Manihot esculenta Crantz), or cassava peels, are evaluated as chemically modified adsorbents with $\mathrm{H}_{2} \mathrm{O}_{2}, \mathrm{H}_{2} \mathrm{SO}_{4}$, and $\mathrm{NaOH}$, in the removal of metal ions $\mathrm{Cd}(\mathrm{II}), \mathrm{Pb}(\mathrm{II})$, and $\mathrm{Cr}(\mathrm{III})$ from contaminated water. Modified adsorbents were chemically characterized for their chemical composition and $\mathrm{pH}_{\mathrm{PZC}}$ (point of zero charge), while adsorption tests determined the best conditions of $\mathrm{pH}$, adsorbent mass, and contact time between adsorbent and adsorbate in the process of removal of the metal ions. Isotherms obtained from the preliminary results were linearized by Langmuir's and Freudlich's models. The thermodynamic parameters, such as $\Delta H, \Delta G$, and $\Delta S$, were also evaluated. The modifying solutions proposed were effective in the modification of adsorbents and resulted in high capacity sorption materials. Equilibrium time between adsorbent and adsorbate for the solutions contaminated with metals is about 40 minutes. The Langmuir model adjusted to most results, indicating monolayers adsorption of $\mathrm{Cd}(\mathrm{II}), \mathrm{Pb}(\mathrm{II})$, and $\mathrm{Cr}(\mathrm{III})$. The values obtained for Langmuir $Q_{m}$ show a higher adsorption capacity caused by chemical modifications, with values such as $19.54 \mathrm{mg} \mathrm{Cd}(\mathrm{II})$ per $\mathrm{g}$ of $\mathrm{M}$. $\mathrm{NaOH}, 42.46 \mathrm{mg}$ of $\mathrm{Pb}$ (II) per g of $\mathrm{M}$. $\mathrm{NaOH}$, and $43.97 \mathrm{mg}$ of $\mathrm{Cr}(\mathrm{III})$ per g of $\mathrm{M} \mathrm{H}_{2} \mathrm{O}_{2}$. Results showed that modified cassava peels are excellent adsorbent, renewable, high availability, and low-cost materials and a feasible alternative in the removal of metals in industries.

\section{Introduction}

Since agroindustries produce several basic products, they have transformed themselves into a symbol of developed societies [1]. However, their various segments are responsible not only for the production of various products but also for several solid wastes. The cassava industry is no exception. Solid wastes are generated in the processing of cassava roots, most of which go to the manufacture of animal feed and biofertilizers. Cassava peel makes up approximately 3 to 5\% of the total mass of roots and about 1 million tons of cassava peels is annually produced in Brazil and 11 million tons worldwide [2]. Since cassava is a crop planted worldwide, with great production and an enormous increasing potential, it is estimated that the above rates will grow considerably in the future.

Another issue also refers to industrial and agricultural activities which cause, directly or indirectly, the contamination of the environment by heavy metals, with great concern and attention for environmental researchers and agencies involved in the control of water pollution [3], especially when the bioaccumulation of metals in aquatic fauna and flora affects human populations and causes irreversible physiological effects with metabolic dysfunctions.

Several techniques reduce contamination but all present disadvantages, especially high installation costs and maintenance. Among the conventional methods, the following are the most employed: chemical precipitation, oxidation or 
reduction, filtration, coagulation, electrochemical treatment, membrane separation processes, and solid phase extraction. Some methods are restricted for technical or economic infeasibility, especially when metals are dissolved in large volumes of water at relatively low concentrations [4].

The adsorption process is an alternative to remove polluting waters. In fact, the technology is being used extensively for the removal of organic pollutants from aqueous solutions. Although activated carbon is one of the most widely used adsorbents, its high cost is a great disadvantage [5] since its production involves physical and chemical activation, as well as high temperature and pressure under controlled conditions [6].

Thus, the use of activated carbon on a large scale, for instance, in the decontamination of large volumes of contaminated water or industrial effluents [7], may not be feasible.

Another research comprises the use of milled vegetable biomass to remove metal ions and pesticides. Some advantages in using plant biomass for wastewater treatment include operational easiness, low-cost processing, reasonable adsorption capacity, selective removal of metal ions, facility of disposal of materials, and easy regeneration [8]. Nevertheless, biomass has not always a very high adsorption capacity [7], which is one of the main restrictions for its use in water remediation. However, some bibliographies already report the use of simple chemical modifications and lowcost biosorbents to increase the adsorptive capacity without increasing the cost of final product $[9,10]$ and, thereby, its widespread use may not be impeded.

Consequently, vegetable biomass is chemically treated with chemical reagents in low-cost solutions such as acids or bases, causing an increase in the pollutant-removing capacity $[11,12]$.

Several studies report that chemical modifications used as biosorbents may introduce functional groups within the structure of the adsorbents or increase their porosity, with an increase in their adsorption capacity $[10,13]$.

Current research evaluates the efficiency of chemically modified cassava peels as adsorbent materials for the removal of toxic metal ions $\mathrm{Cd}(\mathrm{II}), \mathrm{Pb}(\mathrm{II})$, and $\mathrm{Cr}(\mathrm{III})$ from water.

\section{Material and Methods}

2.1. Obtaining Raw Material and Preparation of Modified Adsorbents. Cassava peels were obtained directly from a cassava processing agroindustry in Toledo, PR, Brazil. They were dried at $60^{\circ} \mathrm{C}$ for $48 \mathrm{~h}$, crushed, and sieved (material retained between 14 and 65 mesh) to standardize particle size. Chemical modifications were made to the raw material (cassava peels) such as surface contact area, porosity, number of adsorption sites, and the energy sorption sites, to increase the adsorption of the metals.

Three chemical modifications were evaluated with different chemical reagents by washing with $0.1 \mathrm{~mol} \mathrm{~L}^{-1}$ solutions of $\mathrm{H}_{2} \mathrm{O}_{2}$ (Vetec P.A. 36\%), $\mathrm{H}_{2} \mathrm{SO}_{4}$ (Vetec P.A. 98\%), and $\mathrm{NaOH}$ (Vetec P.A. 99\%) [8, 10, 14].

Solutions were prepared in $0.1 \mathrm{~mol} \mathrm{~L}^{-1}$ of $\mathrm{H}_{2} \mathrm{O}_{2}, \mathrm{H}_{2} \mathrm{SO}_{4}$, and $\mathrm{NaOH}$, to which $70 \mathrm{~mL}$ of solution was added in $125 \mathrm{~mL}$
Erlenmeyer flasks containing $7.0 \mathrm{~g}$ of material in natura (M. in natura).

The Erlenmeyer flasks were placed in a Dubnoff metabolic incubator, at $60^{\circ} \mathrm{C}$ for 6 hours. The modified adsorbents were subsequently washed with distilled water to remove residual reactants still present in the material.

Three chemical modifications applied to cassava peel were evaluated, totaling 3 new modified adsorbents and an adsorbent in its in natura form, namely, $\mathrm{M}$. in natura, $\mathrm{M}$. $\mathrm{H}_{2} \mathrm{O}_{2}, \mathrm{M} . \mathrm{H}_{2} \mathrm{SO}_{4}$, and M. NaOH.

Fortified mono-elementary solutions with metallic ions $\mathrm{Cd}(\mathrm{II}), \mathrm{Pb}(\mathrm{II})$, and $\mathrm{Cr}(\mathrm{III})$ were prepared from salts of cadmium nitrate $\left[\mathrm{Cd}\left(\mathrm{NO}_{3}\right)_{2} \cdot 4 \mathrm{H}_{2} \mathrm{O}\right.$ P.A. $\geq 99.0 \%$ SigmaAldrich], lead nitrate $\left[\mathrm{Pb}\left(\mathrm{NO}_{3}\right)_{2}\right.$ P.A. $\geq 99 \%$ SigmaAldrich], and chromium nitrate $\left[\mathrm{Cr}\left(\mathrm{NO}_{3}\right)_{3} \cdot 9 \mathrm{H}_{2} \mathrm{O}\right.$ P.A. $\geq$ 99\% Sigma-Aldrich]. Solutions were prepared from the mono-elementary solution of $1000 \mathrm{mg} \mathrm{L}^{-1}$, at the desired concentrations for each study, and buffered in $\mathrm{pH}$ rates by adding $\mathrm{NaOH} 0.1 \mathrm{~mol} \mathrm{~L}^{-1} \mathrm{HCl}$ and $0.1 \mathrm{~mol} \mathrm{~L}^{-1}$. The water used in all adsorption experiments was ultrapure (Puritech Permution $\left.{ }^{\circledR}\right)$.

2.2. Characterization of Chemically Modified Adsorbents. The chemical characterization of adsorbents was performed by nitroperchloric digestion of adsorbent materials [15] and concentrations of metals, potassium (K), calcium (Ca), magnesium $(\mathrm{Mg})$, copper $(\mathrm{Cu})$, iron $(\mathrm{Fe})$, manganese $(\mathrm{Mn})$, zinc $(\mathrm{Zn})$, cadmium $(\mathrm{Cd})$, lead $(\mathrm{Pb})$, and chromium $(\mathrm{Cr})$ were determined by flame atomic absorption spectrometry (FAAS) [16], GBC 932 AA (Victoria, Australia) with deuterium lamp for background correction.

The adsorbent's point of zero charge $\left(\mathrm{pH}_{\mathrm{PZC}}\right)$ or rather the $\mathrm{pH}$ at the surface of the adsorbent charges equal to zero was also determined [17].

2.3. Preliminary Studies Involving $p H$ of the Medium and Mass of Adsorbent. A multivariable study was conducted to evaluate the effect of modified adsorbent mass and $\mathrm{pH}$ of mono-elementary solutions of $\mathrm{Cd}(\mathrm{II}), \mathrm{Pb}(\mathrm{II})$, and $\mathrm{Cr}(\mathrm{III})$. In fact, a univariate test of mass and $\mathrm{pH}$ would not be able to determine the possible interactions between the parameters mentioned above. Consequently, the compound center rotational design (CCRD) was employed to determine the influence of each variable and the possible interaction between them, generating an empirical and quadratic mathematical model which is valid within the experimentally tested range [18]. Adsorbents' masses were evaluated between 250 and $1250 \mathrm{mg}$, while $\mathrm{pH}$ ranged between 3.00 and 7.00.

Table 1 shows CCRD planning matrix, displaying the encoded rates and variables of the adsorbent mass and $\mathrm{pH}$ configuration for each mass versus $\mathrm{pH}$ tested.

The solutions were placed in $125 \mathrm{~mL}$ Erlenmeyer flasks containing the mass of the modified adsorbents (Table 1) and subsequently placed in Dubnoff thermostatic system with constant agitation at $200 \mathrm{rpm}$ for $1.5 \mathrm{~h}$.

After performing the sorption process, the samples were filtered and aliquots were removed to determine the concentrations of metals by FAAS [16]. Adsorbed amount 
TABLE 1: CCRD planning matrix (coded and real rates).

\begin{tabular}{lcccc}
\hline Tests & $X_{1}$ & Mass $(\mathrm{mg})$ & $X_{2}$ & $\mathrm{pH}$ \\
\hline 1 & -1.00 & 396.39 & -1.00 & 3.60 \\
2 & 1.00 & 1103.61 & -1.00 & 3.60 \\
3 & -1.00 & 396.39 & 1.00 & 6.40 \\
4 & 1.00 & 1103.61 & 1.00 & 6.40 \\
5 & 0.00 & 750.00 & 0.00 & 5.00 \\
6 & -1.41 & 250.00 & 0.00 & 5.00 \\
7 & 0.00 & 750.00 & 1.41 & 7.00 \\
8 & 1.41 & 1250.00 & 0.00 & 5.00 \\
9 & 0.00 & 750.00 & -1.41 & 3.00 \\
10 & 0.00 & 750.00 & 0.00 & 5.00 \\
11 & 0.00 & 750.00 & 0.00 & 5.00 \\
12 & 0.00 & 750.00 & 0.00 & 5.00 \\
\hline
\end{tabular}

at equilibrium was calculated from rates obtained for the equilibrium concentration:

$$
Q_{\mathrm{eq}}=\left[\frac{\left(C_{0}-C_{\mathrm{eq}}\right)}{m}\right] V
$$

in which $Q_{e q}$ is the amount of ions adsorbed per $1 \mathrm{~g}$ of adsorbent at equilibrium $\left(\mathrm{mg} \mathrm{g}^{-1}\right) ; m$ is the mass of the adsorbent used $(\mathrm{g}) ; C_{0}$ is the initial concentration of the ion $\left(\mathrm{mg} \mathrm{L}^{-1}\right) ; C_{\mathrm{eq}}$ is the concentration of ion in solution at equilibrium $\left(\mathrm{mg} \mathrm{L}^{-1}\right) ; V$ is the volume of solution used $(\mathrm{L})$.

The results of the tests were tabulated and evaluated according to multivariate analysis with Statistica 5.0.

2.4. Studies Involving the Adsorption Kinetics. The adsorption kinetics of metals $\mathrm{Cd}(\mathrm{II}), \mathrm{Pb}(\mathrm{II})$, and $\mathrm{Cr}(\mathrm{III})$ by modified adsorbents was evaluated by studies in which the modified biomass was placed in contact with contaminated monoelementary solutions of the evaluated metals.

A constant mass of $200 \mathrm{mg}$ of the modified adsorbents (determined in Section 2.3, Figure 2) was placed in $125 \mathrm{~mL}$ Erlenmeyer flasks, to which was added $50 \mathrm{~mL}$ of the monoelementary solutions at a concentration of $10 \mathrm{mg} \mathrm{L}^{-1}, \mathrm{pH} 5.0$ (determined in Section 2.3, Figure 2), and temperature at $25^{\circ} \mathrm{C}$.

In the above-mentioned physic-chemical conditions, the absorbed amount of metal was assessed by the following contact times between the modified adsorbent and adsorbate: $10,20,30,40,50,60,80,100,120,140,160$, and 180 minutes. Results were evaluated by the mathematical models of linear pseudo-first order, pseudo-second order, and Elovich and intraparticle diffusion.

The linear pseudo-first order equation, Lagergren's model, is based on the solid adsorption capacity of the equation and the concentration of the solution:

$$
\log \left(Q_{\mathrm{eq}}-Q_{t}\right)=\log Q_{\mathrm{eq}}-\left(\frac{K_{1}}{2.303}\right) t
$$

in which $Q_{\mathrm{eq}}\left(\mathrm{mgg}^{-1}\right)$ and $Q_{t}\left(\mathrm{mg} \mathrm{g}^{-1}\right)$ are the quantity of adsorbate retained per gram of adsorbent at equilibrium at time $t$, respectively; $K_{1}\left(\mathrm{~min}^{-1}\right)$ is the rate constant for pseudo-first order.

The model's occupancy velocity of the active sites is proportional to the number of active sites on the adsorbent material [19]. The applicability of pseudo-first-order model is checked when there is a log graph line $\left(Q_{\mathrm{eq}}-Q_{t}\right)$ versus $t$ [20].

The kinetic model of pseudo-second order (see (3)) is a chemical process, involving the participation of valence forces or electron exchange between the adsorbent and adsorbate [20]:

$$
\frac{t}{Q_{t}}=\frac{1}{\left(K_{2} Q_{\mathrm{eq}}{ }^{2}\right)}+\frac{1}{Q_{\mathrm{eq}}}
$$

in which $K_{2}\left(\mathrm{~g} \mathrm{mg}^{-1} \mathrm{~min}^{-1}\right)$ is the constant of velocity of pseudo-second order. Unlike the pseudo-first-order model, the model predicts the kinetic behavior over the entire adsorption time range [19].

Elovich's kinetic model (see (4)) was first proposed by Roginsky and Zeldovich in 1934 and, according to [21], it has often been employed to describe the chemisorption of gases in solids:

$$
Q_{t}=a+b \ln t
$$

in which $a$ and $b$ are constant, wherein $a$ represents the initial chemisorption velocity $\left(\mathrm{mg} \mathrm{g}^{-1} \mathrm{~min}^{-1}\right)$ and $b$ indicates the number of suitable sites for the adsorption, which is related to the surface coverage extension and activation energy of chemisorption $\left(\mathrm{g} \mathrm{mg}^{-1}\right)$ [22].

The intraparticle diffusion equation (see (5)), derived from Fick's Law, reveals that the distribution of the liquid film surrounding the adsorbent is negligible and the intraparticle diffusion is the only rate that controls the stages of the adsorption process [23]:

$$
Q_{\text {eq }}=K_{\mathrm{id}} t^{0.5}+C_{i}
$$

in which $K_{\mathrm{id}}$ is the intraparticle diffusion constant $\left(\mathrm{mgg}^{-1} \mathrm{~min}^{-1 / 2}\right)$ and $C_{i}$ suggests the thickness of the boundary layer effect $\left(\mathrm{mg} \mathrm{g}^{-1}\right)$ [24].

2.5. Studies of Adsorption Isotherms. Equilibrium studies were developed to assess removal of metals at higher concentrations. Thus, $200 \mathrm{mg}$ of the modified adsorbent masses (determined in Section 2.3, Figure 2) was weighed and placed in $125 \mathrm{~mL}$ Erlenmeyer flasks; $50 \mathrm{~mL}$ of mono-elementary solutions was added with increasing concentrations, at constant conditions, such as pH 5.00 (determined in Section 2.3, Figure 2), constant temperature system $25^{\circ} \mathrm{C}$, and contact time between adsorbent adsorbate of $40 \mathrm{~min}$ (determined in Section 2.4, Figure 3).

The adsorption of metals in the above-mentioned physicochemical conditions was reported at the following pollutant concentrations: $5,20,40,60,80,100,120,140,160$, and $200 \mathrm{~m} \mathrm{~L}^{-1}$. Results were evaluated by Langmuir's and Freundlich's linear models. 
Langmuir's mathematical model is expressed in its linear form by (6) [25]. Consider

$$
\frac{C_{\mathrm{eq}}}{Q_{\mathrm{eq}}}=\frac{1}{\left(Q_{m} K_{L}\right)}+\frac{C_{\mathrm{eq}}}{Q_{m}}
$$

in which $C_{\mathrm{eq}}$ is the ion concentration in equilibrium in the solution $\left(\mathrm{mg} \mathrm{L}^{-1}\right) ;\left(Q_{\mathrm{eq}}\right)$ is the adsorbed amount at equilibrium per unit of mass $\left(\mathrm{mg} \mathrm{g}^{-1}\right) ; Q_{m}$ is the maximum adsorption capacity $\left(\mathrm{mg} \mathrm{g}^{-1}\right) ; K_{L}$ is a constant related to the strength of adsorbent-adsorbate interactions $\left(\mathrm{L} \mathrm{mg}^{-1}\right)$.

The favorability of the isotherm, or rather the favorable or unfavorable behavior of adsorption isotherm, may be interpreted by a constant called equilibrium parameter $\left(R_{L}\right)$ [26] calculated by

$$
R_{L}=\frac{1}{\left(1+K_{L} C_{0}\right)}
$$

in which $C_{0}$ is the initial concentration of higher value $\left(\mathrm{mg} \mathrm{L}^{-1}\right) ; K_{L}$ is the Langmuir constant $\left(\mathrm{L} \mathrm{mg}^{-1}\right)$. Thus, if the rate of $R_{L}$ lies between 0 and 1 , the adsorption process is favorable.

Freundlich's mathematical model (see (8)) describes a multilayer adsorption with an exponential distribution of active sites and, therefore, an equilibrium on heterogeneous surfaces [8].

$$
\log Q_{\text {eq }}=\log K_{f}+\frac{1}{n \log C_{\text {eq }}}
$$

in which $K_{f}$ represents the adsorption capacity $\left(\mathrm{mgg}^{-1}\right) ; n$ indicates the strength of adsorption, related to the heterogeneity of the adsorbent surface.

2.6. Effect of Temperature on the Adsorption Process. The effect of temperature on the metal sorption process by modified adsorbents was also studied by determining some of the thermodynamic parameters. A constant $200 \mathrm{mg}$ mass of modified adsorbents was weighed in $125 \mathrm{~mL}$ Erlenmeyer flasks and $50 \mathrm{~mL}$ of mono-elementary solutions was added at a concentration of $50 \mathrm{mg} \mathrm{L}^{-1}$, at $\mathrm{pH} 5.00$ and contact time between adsorbent and adsorbate at $40 \mathrm{~min}$.

In the above-mentioned experimental conditions, the system temperature was evaluated at $15,25,35,45$, and $55^{\circ} \mathrm{C}$. Results were evaluated by linear models to determine the thermodynamic parameters: $\Delta G, \Delta H$, and $\Delta S$.

The variation of enthalpy $(\Delta H)$ indicates that the adsorption process is endothermic or exothermic and variation of entropy $(\Delta S)$ is connected to the system after the order of the adsorption process [27]. These parameters may be calculated according to (9) $[28,29]$. Consider

$$
\begin{aligned}
\Delta G & =\Delta H-T \Delta S \\
\ln K_{d} & =\left(\frac{\Delta S}{R}\right)-\left(\frac{\Delta H}{R T}\right)
\end{aligned}
$$

in which $K_{d}$ is the division between the amount adsorbed per unit of adsorbent $\left(Q_{\mathrm{eq}}\right)$ and concentration in equilibrium
$\left(C_{\mathrm{eq}}\right) ; R$ is the universal gas constant $\left(8.314 \mathrm{~J} \mathrm{~mol}^{-1} \mathrm{~K}^{-1}\right) ; T$ is the temperature in the experiment (Kelvin). $\Delta H$ and $\Delta S$ rates were obtained from the graph of $\ln K_{d}$ versus $1 / T$.

2.7. Acid Elution for Adsorbents Reuse. The adsorbent masses from the isotherm study (Section 2.5) were recovered and deposited in Erlenmeyer flasks with $50 \mathrm{~mL}$ of $\mathrm{HCl} 0.1 \mathrm{~mol} \mathrm{~L}^{-1}$ at $200 \mathrm{rpm}$ and $25^{\circ} \mathrm{C}$, in order to determine the possibility of reuse of those modified adsorbents. The Erlenmeyer flasks were stirred for $1.5 \mathrm{~h}$ in acid solution, the solution was filtered, and the remaining desorbed concentration of the metal was calculated.

\section{Results}

3.1. Characterization of Chemically Modified Adsorbents. Further, $\mathrm{pH}$ corresponding to the point of zero charge $\left(\mathrm{pH}_{\mathrm{PZC}}\right)$ of the adsorbents $\mathrm{M}$. in natura, $\mathrm{M} . \mathrm{H}_{2} \mathrm{O}_{2}, \mathrm{M} . \mathrm{H}_{2} \mathrm{SO}_{4}$, and $\mathrm{M}$. $\mathrm{NaOH}$ was determined, as illustrated in Figure 1.

According to Figure 1, the zero charge point for the adsorbents $6.02 \mathrm{M}$. in natura, $3.98 \mathrm{M} . \mathrm{H}_{2} \mathrm{O}_{2}$, and $2.05 \mathrm{M}$. $\mathrm{H}_{2} \mathrm{SO}_{4} 7.07$ for $\mathrm{M}$. NaOH may be observed.

The composition of the adsorbents studied by nitroperchloric digestion [15] and the metals by FAAS were determined [16], as Table 2 shows.

According to Table 2, the chemical modifications on the adsorbent (modifications with acid, base, and peroxide) were sufficient to cause changes in the chemical composition of the adsorbent, showing its effectiveness as a modifier solution.

As shown in Table 2, the concentration of $\mathrm{K}, \mathrm{Ca}, \mathrm{Mg}, \mathrm{Cu}$, $\mathrm{Zn}$, and $\mathrm{Pb}$ in the composition of the modified adsorbents was effectively reduced and demonstrated that the modifying solutions $\left(\mathrm{H}_{2} \mathrm{O}_{2}, \mathrm{H}_{2} \mathrm{SO}_{4}\right.$, and $\left.\mathrm{NaOH}\right)$ were extracting solutions, predigesting the biomass, and extracting certain chemical elements of its structure.

It is also notable that the modifier solution $\mathrm{H}_{2} \mathrm{SO}_{4}$, a strong acid recognized as a potent dehydrator, resulted in a higher extraction of metallic elements from cassava peels; this is noted because lower concentrations of the elements $\mathrm{K}, \mathrm{Ca}$, $\mathrm{Mg}, \mathrm{Cu}, \mathrm{Zn}, \mathrm{Fe}$, and $\mathrm{Pb}$ were found in its composition.

3.2. Preliminary Studies Involving $p H$ of the Medium and Mass of Adsorbent. Results obtained at the proposed levels are provided (Table 3 ) for the compound center rotational design (CCRD) for the variables: mass of adsorbent versus $\mathrm{pH}$ of the solution versus quantity adsorbed at equilibrium.

Results shown in Table 3 were subjected to analysis of variance (ANOVA) and are presented in Table 4 . There were significant differences $(\alpha=1 \%)$ for all parameters evaluated with regard to the adsorbents in natura $\mathrm{M} . \mathrm{H}_{2} \mathrm{O}_{2}, \mathrm{M} . \mathrm{H}_{2} \mathrm{SO}_{4}$, and $\mathrm{M} . \mathrm{NaOH}$ in the removal of $\mathrm{Cd}(\mathrm{II}), \mathrm{Pb}(\mathrm{II})$, and $\mathrm{Cr}(\mathrm{III})$ from contaminated solutions.

Table 4 reveals a significant difference of $1 \%$ in all adsorbents studied for the source of mass variation, both as a linear and as a quadratic model. These results showed that the adsorbents $\mathrm{M}$. in natura, $\mathrm{M} . \mathrm{H}_{2} \mathrm{O}_{2}, \mathrm{M} . \mathrm{H}_{2} \mathrm{SO}_{4}$, and $\mathrm{M}$. $\mathrm{NaOH}$ depended closely on the amount of available adsorbent, but not on the $\mathrm{pH}$, at least in this experiment, at the studied range. 
TABLE 2: Mean concentration of elements of the adsorbents.

\begin{tabular}{lcccccccrrr}
\hline Adsorbent & $\mathrm{K}$ & $\begin{array}{c}\mathrm{Ca} \\
\mathrm{g} \mathrm{kg}^{-1}\end{array}$ & $\mathrm{Mg}$ & $\mathrm{Cu}$ & $\mathrm{Zn}$ & $\mathrm{Mn}$ & $\begin{array}{c}\mathrm{Fe} \\
\mathrm{mg} \mathrm{kg}^{-1}\end{array}$ & $\mathrm{Cd}$ & $\mathrm{Pb}$ & $\mathrm{Cr}$ \\
\hline M. in natura & 24.10 & 35.03 & 6.83 & 14.33 & 32.00 & 123.33 & 335.66 & $>0.005$ & 13.00 & $>0.01$ \\
$\mathrm{M} . ~_{2} \mathrm{O}_{2}$ & 7.84 & 5.68 & 1.27 & 10.60 & 32.20 & 121.50 & 333.70 & $>0.005$ & 10.40 & $>0.01$ \\
$\mathrm{M} . ~_{2} \mathrm{SO}_{4}$ & 5.78 & 3.41 & 0.43 & 4.30 & 20.40 & 115.70 & 330.90 & $>0.005$ & 5.10 & $>0.01$ \\
$\mathrm{M} . \mathrm{NaOH}$ & 11.22 & 6.52 & 1.49 & 4.80 & 32.60 & 122.00 & 331.60 & $>0.005$ & 11.50 & $>0.01$ \\
\hline
\end{tabular}

QL (quantification limit): $\mathrm{K}=0.01 ; \mathrm{Ca}=0.005 ; \mathrm{Mg}=0.005 ; \mathrm{Cu}=0.005 ; \mathrm{Fe}=0.01 ; \mathrm{Mn}=0.01 ; \mathrm{Zn}=0.005 ; \mathrm{Cd}=0.005 ; \mathrm{Pb}=0.01 ; \mathrm{Cr}=0.01\left(\mathrm{mg} \mathrm{kg}^{-1}\right)$.

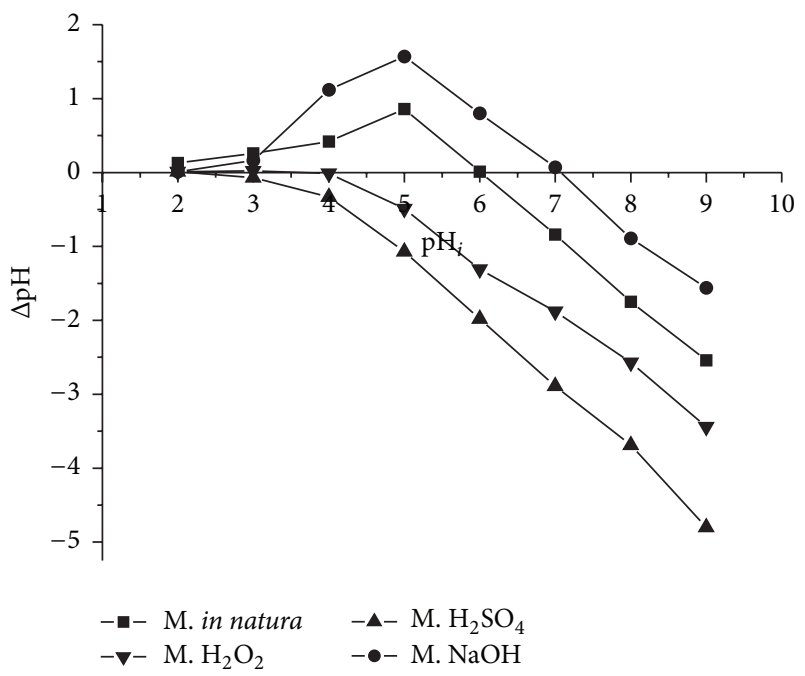

Figure 1: $\mathrm{pH}_{\text {PZC }}$ for the adsorbents $\mathrm{M}$. in natura, M. $\mathrm{H}_{2} \mathrm{O}_{2}, \mathrm{M}$. $\mathrm{H}_{2} \mathrm{SO}_{4}$, and $\mathrm{M}$. $\mathrm{NaOH}$.

This result is excellent, because the modified adsorbents studied in this research may be used in a wide $\mathrm{pH}$ range, still maintaining high efficiency removal of these metals.

Figure 2 illustrates the response surfaces for the adsorption of $\mathrm{Cd}(\mathrm{II}), \mathrm{Pb}(\mathrm{II})$, and $\mathrm{Cr}(\mathrm{III})$ by adsorbents $\mathrm{M}$. in natura, M. $\mathrm{H}_{2} \mathrm{O}_{2}, \mathrm{M} . \mathrm{H}_{2} \mathrm{SO}_{4}$, and M. NaOH.

As may be seen in Figure 2 and Table 4, within the experimental conditions of this study, the $\mathrm{pH}$ ranges did not influence the adsorption of $\mathrm{Cd}(\mathrm{II}), \mathrm{Pb}(\mathrm{II})$, or $\mathrm{Cr}(\mathrm{III})$. However, higher adsorption rates of the metals $\mathrm{Cd}(\mathrm{II}), \mathrm{Pb}(\mathrm{II})$, and $\operatorname{Cr}(\mathrm{III})$, measured by the adsorbed amount $\left(Q_{\mathrm{eq}}\right.$ or $\left.Q_{\mathrm{ads}}\right)$, occurred closer to the adsorbent mass $200 \mathrm{mg}$.

The number of active sites available depends on the amount of the adsorbent; then studies to verify the ideal mass adsorption are fundamental, because according to Rubio et al. [30] in certain cases there may be a decrease of the amount adsorbed due to formation of agglomerates which would reduce the total surface area and the number of active sites available for the process.

Response surfaces in Figure 2 are adjusted mathematically by the multiple linear regression equations $(x, y, z)$ for the removal of $\mathrm{Cd}(\mathrm{II}), \mathrm{Pb}(\mathrm{II})$, and $\mathrm{Cr}(\mathrm{III})$ by the modified adsorbents and in natura (Table 5).

3.3. Studies Involving Adsorption Kinetics. Figure 3 shows the results obtained for removal of metals $\mathrm{Cd}(\mathrm{II}), \mathrm{Pb}(\mathrm{II})$, and $\mathrm{Cr}(\mathrm{III})$ by adsorbents $\mathrm{M} . \mathrm{H}_{2} \mathrm{O}_{2}, \mathrm{M} . \mathrm{H}_{2} \mathrm{SO}_{4}$, and $\mathrm{M}$. $\mathrm{NaOH}$ and the effect of contact time between the adsorbentmodified solutions and $\mathrm{Cd}(\mathrm{II}), \mathrm{Pb}(\mathrm{II})$, and $\mathrm{Cr}(\mathrm{III})$.

Results in Figure 3, or rather the influence of contact time between adsorbate and adsorbent, were linearized by mathematical models of pseudo-first order, pseudo-second order, and Elovich and intraparticle diffusion for the adsorbents $\mathrm{M}$. $\mathrm{H}_{2} \mathrm{O}_{2}, \mathrm{M} . \mathrm{H}_{2} \mathrm{SO}_{4}$, and $\mathrm{M}$. $\mathrm{NaOH}$ used for the removal of $\mathrm{Cd}(\mathrm{II}), \mathrm{Pb}(\mathrm{II})$, and $\mathrm{Cr}(\mathrm{III})$ from contaminated water.

Tables 6 and 7 present the results of the kinetic parameters inherent to linearization by the models of pseudo-first order, pseudo-second order, and Elovich and intraparticle diffusion.

In a preliminary analysis of the data of all the kinetic models evaluated (Tables 6 and 7), the pseudo-secondorder model proved to be the best mathematical adjustment for adsorption of $\mathrm{Cd}(\mathrm{II}), \mathrm{Pb}(\mathrm{II})$, and $\mathrm{Cr}(\mathrm{III})$ by modified adsorbents $\mathrm{M} . \mathrm{H}_{2} \mathrm{O}_{2}, \mathrm{M} . \mathrm{H}_{2} \mathrm{SO}_{4}$, and $\mathrm{M}$. NaOH.

The intraparticle diffusion model presupposes the occurrence of diffusion of the adsorbate particle $(\mathrm{Cd}, \mathrm{Pb}$, and $\mathrm{Cr}$ in this study) into the adsorbent particle $\left(\mathrm{M} . \mathrm{H}_{2} \mathrm{O}_{2}, \mathrm{M} . \mathrm{H}_{2} \mathrm{SO}_{4}\right.$, and $\mathrm{M} . \mathrm{NaOH}$ in this study). Data reveal the possibility of the occurrence of diffusion intraparticle at various stages in this way; straight line fragmentation was performed in two segments, so that adjustment diffusion model occurs in at least one of the intervals at the evaluated time, as shown in Table 7 for the $\mathrm{M} \mathrm{H}_{2} \mathrm{SO}_{4}$ adsorbent in removing $\mathrm{Cd}(\mathrm{II})$.

Similarly, in Table 6, straight fragmentation was also performed for the better model adjustments of Elovich for the adsorbent $\mathrm{M} . \mathrm{H}_{2} \mathrm{SO}_{4}$ in removing $\mathrm{Cd}(\mathrm{II})$. However, despite the straight fragmentation, a good adjustment $\left(R^{2}\right)$ was not found for the observed data, so that the models of pseudo-first order, Elovich, and intraparticle diffusion failed to demonstrate a satisfactory adsorption of $\mathrm{Cd}(\mathrm{II}), \mathrm{Pb}(\mathrm{II})$, and $\mathrm{Cr}(\mathrm{III})$ by $\mathrm{M}$. $\mathrm{H}_{2} \mathrm{O}_{2}$ materials, $\mathrm{M} \mathrm{H}_{2} \mathrm{SO}_{4}$ and $\mathrm{M}$. NaOH.

Only one exception was observed; the adsorbent $\mathrm{M}$. $\mathrm{H}_{2} \mathrm{SO}_{4}$ in the removal of $\mathrm{Cr}(\mathrm{III})$ showed good adjustment $\left(R^{2}\right)$ of the model Elovich. These results will be described and discussed in the following sections.

3.4. Studies of Adsorption Isotherms. Results for sorption equilibrium tests constructed $\mathrm{Cd}(\mathrm{II}), \mathrm{Pb}(\mathrm{II})$, and $\mathrm{Cr}(\mathrm{III})$ adsorption isotherms, which were linearized by Langmuir's and Freundlich's mathematical models, as shown in Table 8.

Rates in Table 8 reveal a predominance of good mathematical adjustments to Langmuir's model, which suggests the occurrence of the adsorption of monolayers of $\mathrm{Cd}(\mathrm{II}), \mathrm{Pb}(\mathrm{II})$, 

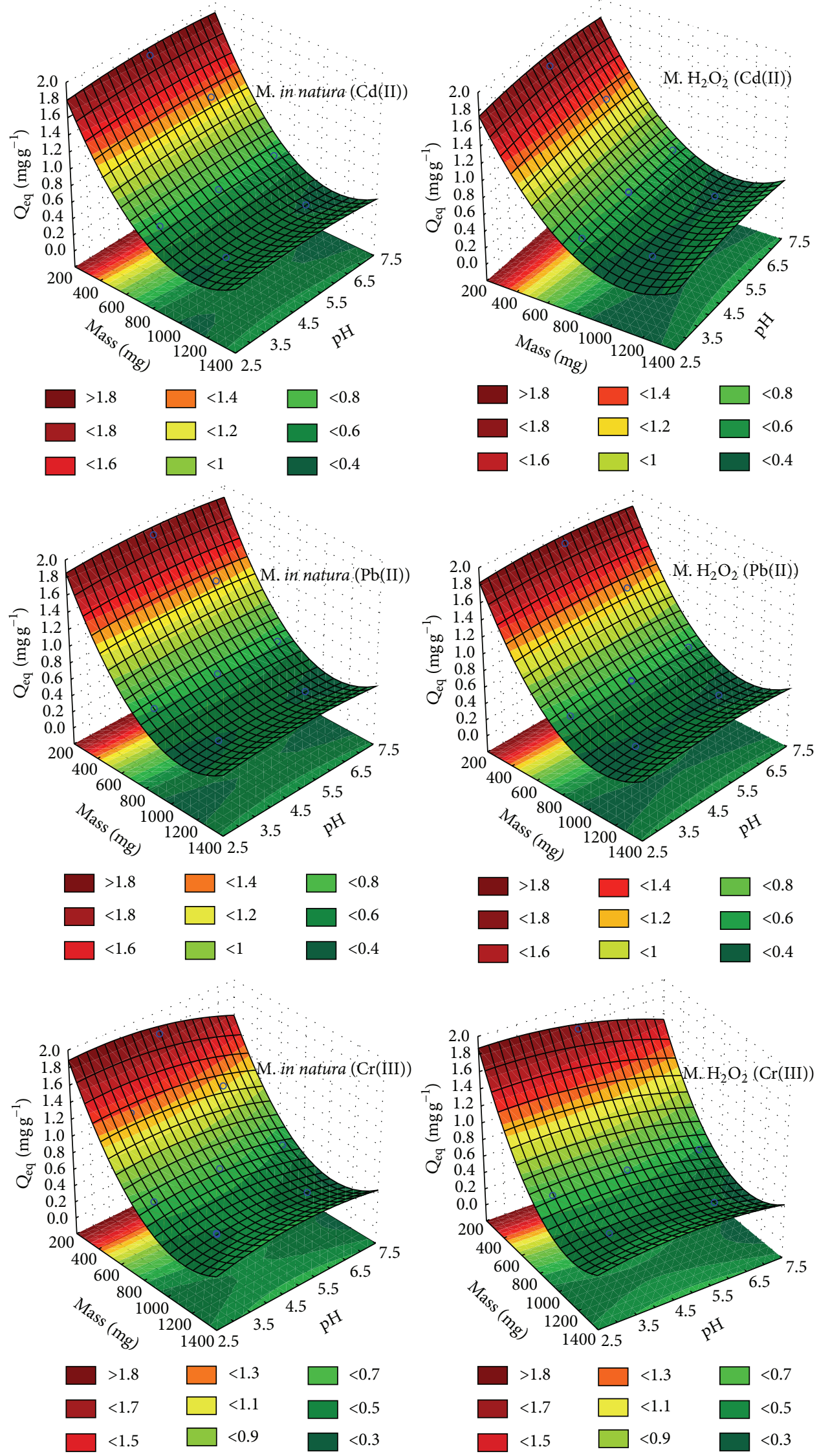

Figure 2: Continued. 

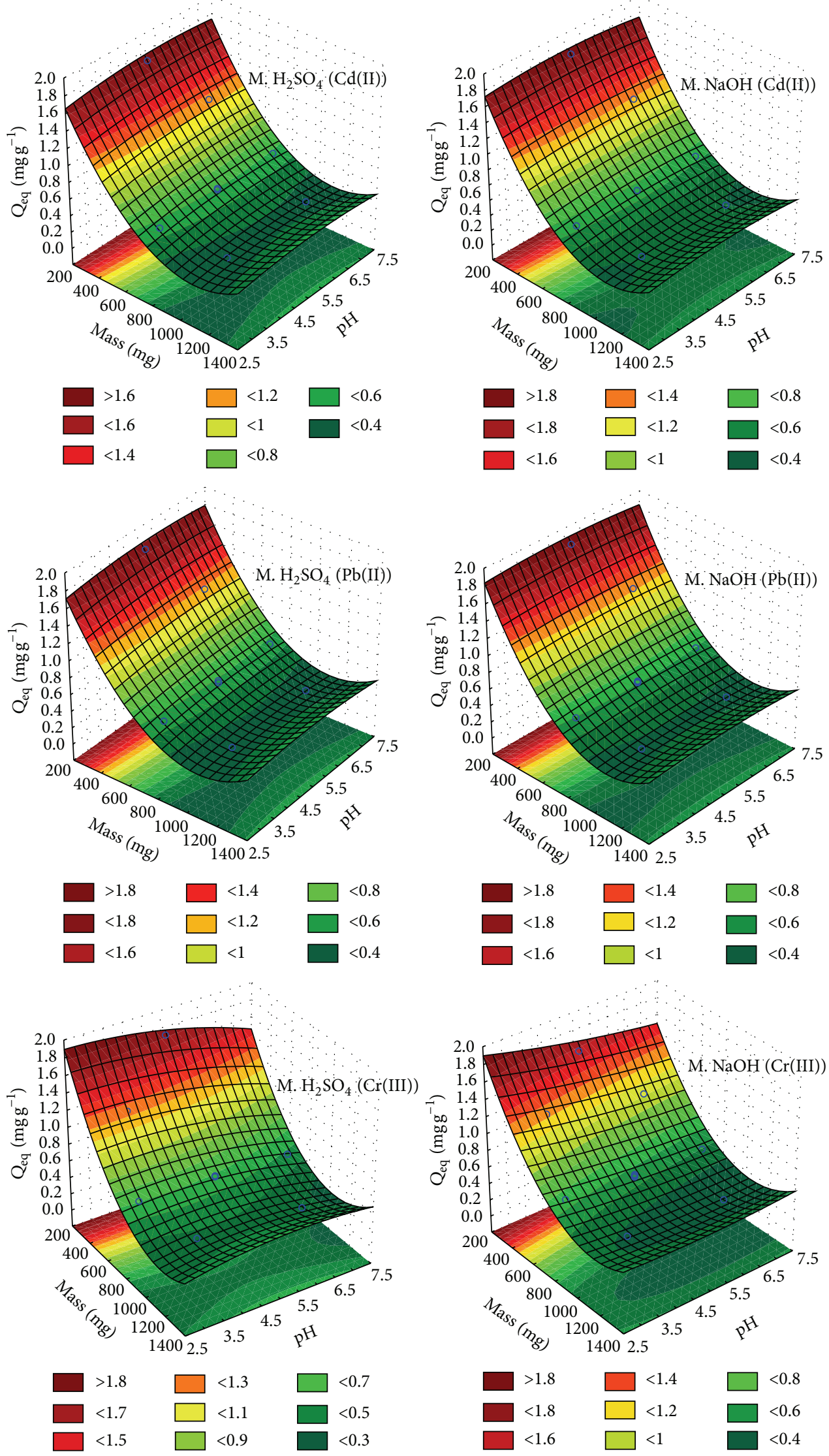

FIGURE 2: Graphs of response surfaces obtained in the adsorption of $\mathrm{Cd}(\mathrm{II}), \mathrm{Pb}(\mathrm{II})$, and $\mathrm{Cr}(\mathrm{III})$ by modified materials from cassava peels depending on adsorbent mass and $\mathrm{pH}$ of the mono-elementary solutions. 

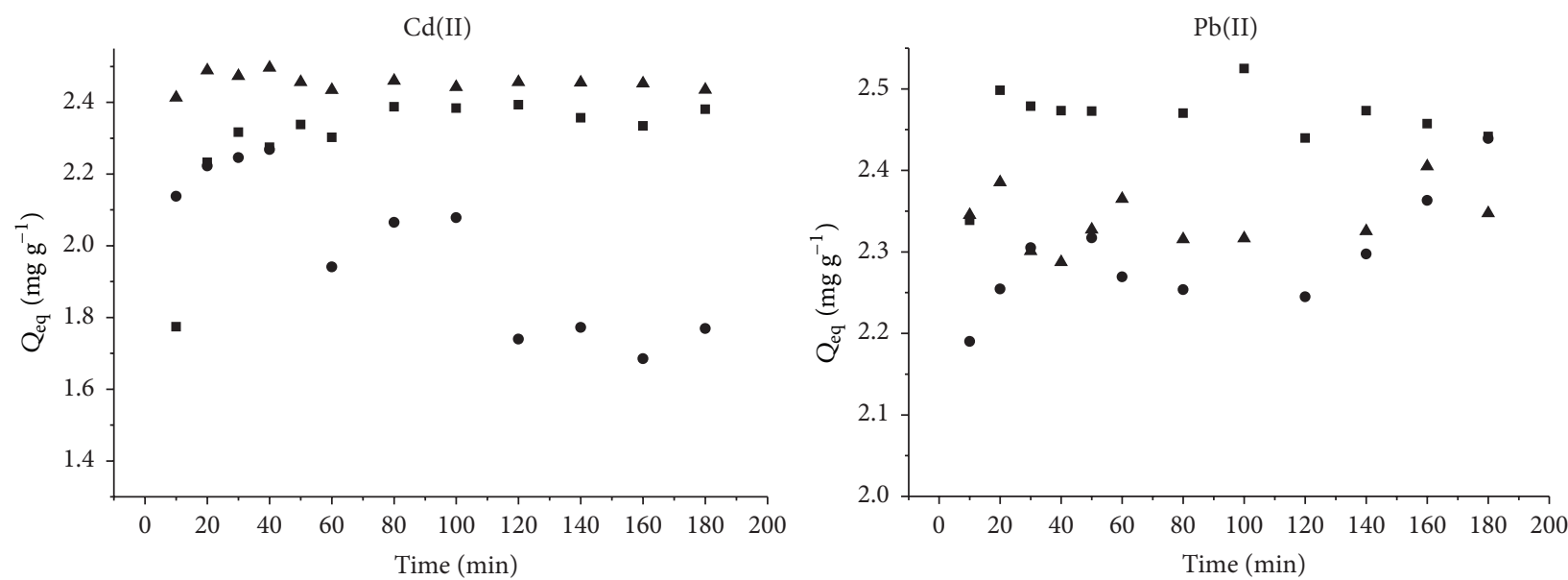

- M. $\mathrm{H}_{2} \mathrm{O}_{2}$

- $\mathrm{M} . \mathrm{H}_{2} \mathrm{SO}_{4}$

- M. $\mathrm{H}_{2} \mathrm{O}_{2}$

- M. $\mathrm{H}_{2} \mathrm{SO}_{4}$

\ $\mathrm{M} . \mathrm{NaOH}$

- $\mathrm{M} . \mathrm{NaOH}$

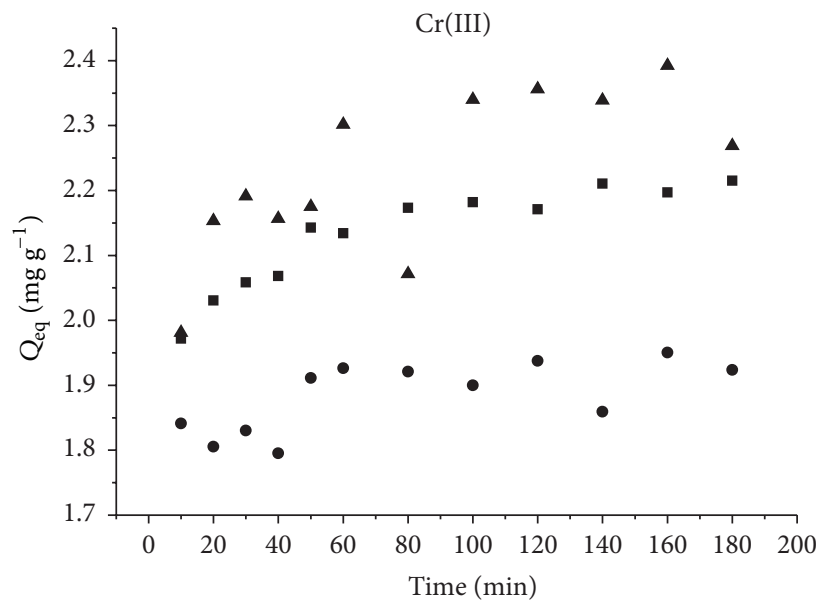

- M. $\mathrm{H}_{2} \mathrm{O}_{2}$

- $\mathrm{M} . \mathrm{H}_{2} \mathrm{SO}_{4}$

- M. $\mathrm{NaOH}$

FIGURE 3: Physical-chemical equilibrium time between modified adsorbents and mono-elementary solutions of $\mathrm{Cd}(\mathrm{II}), \mathrm{Pb}(\mathrm{II})$, and $\mathrm{Cr}$ (III).

and $\mathrm{Cr}$ (III) in current study. This is due to $R^{2}$ rates being close to 1.0 , indicating good mathematical adjustment, as noted in the following modified adsorbents: $\mathrm{M} . \mathrm{H}_{2} \mathrm{O}_{2}, \mathrm{M} . \mathrm{H}_{2} \mathrm{SO}_{4}$, and $\mathrm{M} . \mathrm{NaOH}$ in adsorption of $\mathrm{Cd}(\mathrm{II}) ; \mathrm{M} . \mathrm{H}_{2} \mathrm{O}_{2}$ and $\mathrm{M}$. $\mathrm{NaOH}$ in adsorption of $\mathrm{Pb}(\mathrm{II})$; and $\mathrm{M} . \mathrm{H}_{2} \mathrm{O}_{2}$ and $\mathrm{M}_{2} \mathrm{H}_{2} \mathrm{SO}_{4}$ in adsorption of $\mathrm{Cr}$ (III).

However, there was a good adjustment $\left(R^{2}\right)$ to the Freundlich's model in some specific cases, which suggests the occurrence of multilayer adsorption: $\mathrm{M}$. $\mathrm{H}_{2} \mathrm{SO}_{4}$ adsorption of $\mathrm{Cd}(\mathrm{II}) ; \mathrm{M} . \mathrm{H}_{2} \mathrm{O}_{2}$ and $\mathrm{M} . \mathrm{H}_{2} \mathrm{SO}_{4}$ in adsorption of $\mathrm{Pb}(\mathrm{II})$.

When data are confronted (Table 8), they suggest the occurrence of adsorption in mono- or multilayer used as the adsorbent $\mathrm{M} . \mathrm{H}_{2} \mathrm{SO}_{4}$ in removing $\mathrm{Cd}(\mathrm{II})$, similar to $\mathrm{M}$. $\mathrm{H}_{2} \mathrm{O}_{2}$ removing $\mathrm{Pb}(\mathrm{II})$. Therefore, these cases reveal good mathematical adjustments to Langmuir's and Freundlich's model. This behavior and other linear parameters of these mathematical models will be discussed below.

3.5. Effect of Temperature on the Adsorption Process. The influence of temperature on the removing process of metals $\mathrm{Cd}(\mathrm{II}), \mathrm{Pb}(\mathrm{II})$, and $\mathrm{Cr}(\mathrm{III})$ by modified adsorbents $\mathrm{M}$. $\mathrm{H}_{2} \mathrm{O}_{2}$, M. $\mathrm{H}_{2} \mathrm{SO}_{4}$, and $\mathrm{M}$. $\mathrm{NaOH}$ was evaluated. Results are given in Table 9.

Table 9 demonstrates that the amount of adsorbed metal $\left(Q_{\text {eq }}\right)$ was different for the adsorbents studied. Higher removal rates occurred by raising the system temperature in the removal of $\mathrm{Cd}(\mathrm{II})$ adsorbents $\mathrm{M} . \mathrm{H}_{2} \mathrm{SO}_{4}$ and $\mathrm{M} . \mathrm{H}_{2} \mathrm{O}_{2}$, and adsorbent for adsorption $\mathrm{M}$. $\mathrm{NaOH} \mathrm{Cr}(\mathrm{III})$.

Contrastingly, the removal of $\mathrm{Cd}(\mathrm{II})$ by the adsorbent $\mathrm{M}$. $\mathrm{NaOH}$ and the removal of $\mathrm{Pb}$ (II) and $\mathrm{Cr}$ (III) by the adsorbent 
TABLE 3: Planning matrix CCRD with quadruplicate at the midpoint and average adsorption rates of $\mathrm{Cd}(\mathrm{II}), \mathrm{Pb}$ (II), and $\mathrm{Cr}$ (III) to adsorbents in natura and chemically modified with $\mathrm{H}_{2} \mathrm{O}_{2}, \mathrm{H}_{2} \mathrm{SO}_{4}$, and $\mathrm{NaOH}$ solutions.

\begin{tabular}{|c|c|c|c|c|c|c|c|c|c|c|c|c|c|c|}
\hline \multirow[b]{2}{*}{ Tests } & \multicolumn{2}{|c|}{ Variable } & \multicolumn{4}{|c|}{$Q_{\mathrm{eq}}\left(\mathrm{mg} \mathrm{g}^{-1}\right) \mathrm{Cd}(\mathrm{II})$} & \multicolumn{4}{|c|}{$Q_{\mathrm{eq}}\left(\mathrm{mg} \mathrm{g}^{-1}\right) \mathrm{Pb}(\mathrm{II})$} & \multicolumn{4}{|c|}{$Q_{\mathrm{eq}}\left(\mathrm{mg} \mathrm{g}^{-1}\right) \operatorname{Cr}(\mathrm{III})$} \\
\hline & $\begin{array}{l}\text { Mass } \\
(\mathrm{mg})\end{array}$ & $\mathrm{pH}$ & $\begin{array}{l}\text { M. in } \\
\text { natura }\end{array}$ & $\begin{array}{c}\text { M. } \\
\mathrm{H}_{2} \mathrm{O}_{2} \\
\end{array}$ & $\begin{array}{c}\mathrm{M} . \\
\mathrm{H}_{2} \mathrm{SO}_{4}\end{array}$ & $\begin{array}{c}\mathrm{M} . \\
\mathrm{NaOH}\end{array}$ & $\begin{array}{l}\text { M. in } \\
\text { natura }\end{array}$ & $\begin{array}{c}\text { M. } \\
\mathrm{H}_{2} \mathrm{O}_{2}\end{array}$ & $\begin{array}{c}\mathrm{M} . \\
\mathrm{H}_{2} \mathrm{SO}_{4} \\
\end{array}$ & $\begin{array}{c}\mathrm{M} . \\
\mathrm{NaOH} \\
\end{array}$ & $\begin{array}{l}\text { M. in } \\
\text { natura }\end{array}$ & $\begin{array}{c}\text { M. } \\
\mathrm{H}_{2} \mathrm{O}_{2} \\
\end{array}$ & $\begin{array}{c}\mathrm{M} . \\
\mathrm{H}_{2} \mathrm{SO}_{4} \\
\end{array}$ & $\begin{array}{c}\mathrm{M} . \\
\mathrm{NaOH}\end{array}$ \\
\hline 1 & 396.39 & 3.60 & 1.158 & 1.157 & 1.065 & 1.231 & 1.191 & 1.179 & 1.089 & 1.176 & 1.220 & 1.201 & 1.242 & 1.217 \\
\hline 2 & 1103.61 & 3.60 & 0.434 & 0.418 & 0.379 & 0.448 & 0.428 & 0.421 & 0.397 & 0.421 & 0.440 & 0.437 & 0.447 & 0.437 \\
\hline 3 & 396.39 & 6.40 & 1.210 & 1.163 & 1.120 & 1.239 & 1.198 & 1.175 & 1.131 & 1.177 & 0.950 & 0.992 & 1.066 & 0.986 \\
\hline 4 & 1103.61 & 6.40 & 0.435 & 0.419 & 0.413 & 0.449 & 0.427 & 0.422 & 0.404 & 0.419 & 0.339 & 0.342 & 0.376 & 0.340 \\
\hline 5 & 750.00 & 5.00 & 0.646 & 0.596 & 0.602 & 0.661 & 0.630 & 0.621 & 0.590 & 0.617 & 0.595 & 0.597 & 0.623 & 0.561 \\
\hline 6 & 250.00 & 5.00 & 1.875 & 1.783 & 1.748 & 1.983 & 1.890 & 1.856 & 1.795 & 1.855 & 1.766 & 1.795 & 1.809 & 1.596 \\
\hline 7 & 750.00 & 7.00 & 0.638 & 0.623 & 0.606 & 0.659 & 0.629 & 0.607 & 0.590 & 0.615 & 0.532 & 0.535 & 0.534 & 0.520 \\
\hline 8 & 1250.00 & 5.00 & 0.388 & 0.369 & 0.365 & 0.392 & 0.378 & 0.369 & 0.356 & 0.366 & 0.358 & 0.358 & 0.368 & 0.335 \\
\hline 9 & 750.00 & 3.00 & 0.647 & 0.549 & 0.582 & 0.658 & 0.626 & 0.611 & 0.578 & 0.614 & 0.599 & 0.611 & 0.607 & 0.639 \\
\hline 10 & 750.00 & 5.00 & 0.598 & 0.604 & 0.605 & 0.658 & 0.622 & 0.614 & 0.585 & 0.613 & 0.580 & 0.594 & 0.612 & 0.542 \\
\hline 11 & 750.00 & 5.00 & 0.644 & 0.613 & 0.576 & 0.659 & 0.627 & 0.612 & 0.588 & 0.607 & 0.591 & 0.595 & 0.619 & 0.531 \\
\hline 12 & 750.00 & 5.00 & 0.648 & 0.612 & 0.588 & 0.656 & 0.629 & 0.615 & 0.567 & 0.603 & 0.589 & 0.597 & 0.620 & 0.538 \\
\hline
\end{tabular}

TABLE 4: Mean square and summary of analysis of variance (ANOVA) are displayed to forecast model for the influence of the masses of cassava and $\mathrm{pH}$ solution on the removal of $\mathrm{Cd}(\mathrm{II}), \mathrm{Pb}(\mathrm{II})$, and $\mathrm{Cr}(\mathrm{III})$ to the adsorbents in natura and modified.

\begin{tabular}{|c|c|c|c|c|c|c|c|c|c|c|c|c|c|}
\hline \multirow[b]{2}{*}{ FV } & \multicolumn{5}{|c|}{ Cd(II) } & \multicolumn{3}{|c|}{$\mathrm{Pb}(\mathrm{II})$} & \multicolumn{5}{|c|}{$\mathrm{Cr}(\mathrm{III})$} \\
\hline & GL & $\begin{array}{l}\text { M. in } \\
\text { natura }\end{array}$ & $\begin{array}{c}\text { M. } \\
\mathrm{H}_{2} \mathrm{O}_{2}\end{array}$ & $\begin{array}{c}\mathrm{M} . \\
\mathrm{H}_{2} \mathrm{SO}_{4}\end{array}$ & $\begin{array}{c}\mathrm{M} . \\
\mathrm{NaOH}\end{array}$ & $\begin{array}{l}\text { M. in } \\
\text { natura }\end{array}$ & $\begin{array}{c}\mathrm{M} . \\
\mathrm{H}_{2} \mathrm{O}_{2}\end{array}$ & $\begin{array}{c}\mathrm{M} . \\
\mathrm{H}_{2} \mathrm{SO}_{4}\end{array}$ & $\begin{array}{c}\mathrm{M} . \\
\mathrm{NaOH}\end{array}$ & $\begin{array}{l}\text { M. in } \\
\text { natura }\end{array}$ & $\begin{array}{c}\text { M. } \\
\mathrm{H}_{2} \mathrm{O}_{2}\end{array}$ & $\begin{array}{c}\mathrm{M} . \\
\mathrm{H}_{2} \mathrm{SO}_{4}\end{array}$ & $\begin{array}{c}\mathrm{M} . \\
\mathrm{NaOH}\end{array}$ \\
\hline Mass (L) & 1 & $1.621^{* *}$ & $1.516^{* *}$ & $1.401^{* *}$ & $1.827^{* *}$ & $1.685^{* *}$ & $1.633^{* *}$ & $1.492^{* *}$ & $1.635^{* *}$ & $1.430^{* *}$ & $1.483^{* *}$ & $1.549^{* *}$ & $1.287^{* *}$ \\
\hline Mass (Q) & 1 & $0.335^{* *}$ & $0.322^{* *}$ & $0.287^{* *}$ & $0.382^{* *}$ & $0.356^{* *}$ & $0.348^{* *}$ & $0.332^{* *}$ & $0.350^{* *}$ & $0.302^{* *}$ & $0.310^{* *}$ & $0.319^{* *}$ & $0.267^{* *}$ \\
\hline $\mathrm{pH}(\mathrm{L})$ & 1 & 0.000 & 0.001 & 0.001 & 0.000 & 0.000 & 0.000 & 0.000 & 0.000 & 0.027 & 0.021 & 0.015 & 0.030 \\
\hline $\mathrm{pH}(\mathrm{Q})$ & 1 & 0.001 & 0.002 & 0.002 & 0.002 & 0.001 & 0.002 & 0.002 & 0.001 & 0.006 & 0.006 & 0.008 & 0.000 \\
\hline Mass $\times p H$ & 1 & 0.000 & 0.000 & 0.000 & 0.000 & 0.000 & 0.000 & 0.000 & 0.000 & 0.007 & 0.003 & 0.002 & 0.004 \\
\hline Total & 6 & 0.009 & 0.006 & 0.008 & 0.011 & 0.009 & 0.008 & 0.009 & 0.008 & 0.011 & 0.010 & 0.007 & 0.003 \\
\hline Residue & 11 & & & & & & & & & & & & \\
\hline
\end{tabular}

** Significant at $1 \%$.

TABLE 5: Multiple quadratic mathematical equations obtained from the response surfaces for adsorption of $\mathrm{Cd}(\mathrm{II}), \mathrm{Pb}(\mathrm{II})$, and $\mathrm{Cr}$ (III) by adsorbents based on cassava peels, chemically modified and in natura.

\begin{tabular}{|c|c|c|c|}
\hline & Adsorbents & Equations & $R^{2}$ \\
\hline \multirow{4}{*}{$\mathrm{Cd}$} & M. in natura & $z=2.31392-0.00389216 x+0.00000183 x^{2}+0.0994207 y-0.00765268 y^{2}-0.00002575 x y$ & 0.970 \\
\hline & M. $\mathrm{H}_{2} \mathrm{O}_{2}$ & $z=2.22661-0.00391300 x+0.00000179 x^{2}+0.1135094 y-0.010198 y^{2}-0.0000021231 x y$ & 0.979 \\
\hline & M. $\mathrm{H}_{2} \mathrm{SO}_{4}$ & $z=2.09311-0.00367333 x+0.00000169 x^{2}+0.117596 y-0.0099065 y^{2}-0.00001022567 x y$ & 0.969 \\
\hline & M. $\mathrm{NaOH}$ & $z=2.49556-0.00426238 x+0.00000195 x^{2}+0.106341 y-0.01022994 y^{2}-0.00000413033 x y$ & 0.969 \\
\hline \multirow{4}{*}{$\mathrm{Pb}$} & M. in natura & $z=2.42402-0.00410920 x+0.00000188 x^{2}+0.091384 y-0.00873871 y^{2}-0.00000392186 x y$ & 0.973 \\
\hline & M. $\mathrm{H}_{2} \mathrm{O}_{2}$ & $z=2.40349-0.00408627 x+0.00000186 x^{2}+0.090141 y-0.0092527 y^{2}+0.0000022304 x y$ & 0.975 \\
\hline & M. $\mathrm{H}_{2} \mathrm{SO}_{4}$ & $z=2.20750-0.00386993 x+0.00000182 x^{2}+0.108006 y-0.008937 y^{2}-0.0000172072 x y$ & 0.969 \\
\hline & M. $\mathrm{NaOH}$ & $z=2.44355-0.00408057 x+0.00000187 x^{2}+0.0706209 y-0.006958 y^{2}-0.0000014771 x y$ & 0.974 \\
\hline \multirow{4}{*}{$\mathrm{Cr}$} & M. in natura & $z=2.60020-0.00422655 x+0.00000173 x^{2}+0.04990993 y-0.015409 y^{2}+0.00008415263 x y$ & 0.964 \\
\hline & M. $\mathrm{H}_{2} \mathrm{O}_{2}$ & $z=2.49313-0.00414079 x+0.00000176 x^{2}+0.08114590 y-0.015967 y^{2}+0.00005636427 x y$ & 0.965 \\
\hline & M. $\mathrm{H}_{2} \mathrm{SO}_{4}$ & $z=2.46274-0.00418541 x+0.00000178 x^{2}+0.10776064 y-0.0177875 y^{2}+0.0000522846 x y$ & 0.977 \\
\hline & M. $\mathrm{NaOH}$ & $z=2.92410-0.00392245 x+0.00000163 x^{2}-0.149982207 y+0.005562 y^{2}+0.00006738493 x y$ & 0.986 \\
\hline
\end{tabular}

$x=\operatorname{adsorbent}$ mass $(\mathrm{mg}) ; y=\mathrm{pH}$ of the contaminant solution; $z=$ adsorbed quantity $\left(\mathrm{mg} \mathrm{g}^{-1}\right)$. 
TABLE 6: Kinetic parameters referred to linear models of pseudo-first order, pseudo-second order, and Elovich obtained by adsorbents M. $\mathrm{H}_{2} \mathrm{O}_{2}, \mathrm{M}_{2} \mathrm{H}_{2} \mathrm{SO}_{4}$, and $\mathrm{M}$. NaOH in the removal of $\mathrm{Cd}(\mathrm{II}), \mathrm{Pb}(\mathrm{II})$, and $\mathrm{Cr}(\mathrm{III})$ from water.

\begin{tabular}{|c|c|c|c|c|c|c|c|c|c|c|}
\hline \multirow[t]{2}{*}{ Parameters/adsorbents } & \multirow[t]{2}{*}{ M. $\mathrm{H}_{2} \mathrm{O}_{2}$} & $\begin{array}{c}\text { M. } \mathrm{H}_{2} \mathrm{SO}_{4} \\
\text { (Line A) }\end{array}$ & $\begin{array}{c}\text { M. } \mathrm{H}_{2} \mathrm{SO}_{4} \\
\text { (Line B) }\end{array}$ & M. $\mathrm{NaOH}$ & $\begin{array}{c}\text { M. } \\
\mathrm{H}_{2} \mathrm{O}_{2}\end{array}$ & $\begin{array}{c}\mathrm{M} . \\
\mathrm{H}_{2} \mathrm{SO}_{4}\end{array}$ & $\begin{array}{c}\mathrm{M} . \\
\mathrm{NaOH}\end{array}$ & $\begin{array}{c}\text { M. } \\
\mathrm{H}_{2} \mathrm{O}_{2}\end{array}$ & $\begin{array}{c}\mathrm{M} . \\
\mathrm{H}_{2} \mathrm{SO}_{4}\end{array}$ & $\begin{array}{c}\mathrm{M} . \\
\mathrm{NaOH}\end{array}$ \\
\hline & & \multicolumn{2}{|c|}{$\mathrm{Cd}(\mathrm{II})$} & & \multicolumn{3}{|c|}{$\mathrm{Pb}(\mathrm{II})$} & \multicolumn{3}{|c|}{$\mathrm{Cr}(\mathrm{III})$} \\
\hline \multicolumn{11}{|l|}{ Pseudo-first order } \\
\hline$K_{1}\left(\min ^{-1}\right)$ & -0.0397 & 0.0084 & & 0.0008 & -0.0059 & -0.0046 & -0.0053 & -0.0161 & -0.0218 & -0.0184 \\
\hline$Q_{\mathrm{eq}}(\mathrm{cal}).\left(\mathrm{mg} \mathrm{g}^{-1}\right)$ & 0.3846 & 0.1339 & & 0.0425 & 0.1757 & 0.2365 & 0.2338 & 0.2160 & 0.1404 & 0.3513 \\
\hline$R^{2}$ & 0.778 & 0.707 & & 0.034 & 0.740 & 0.578 & 0.857 & 0.921 & 0.908 & 0.878 \\
\hline \multicolumn{11}{|l|}{ Pseudo-second order } \\
\hline$K_{2}\left(\mathrm{~g} \mathrm{mg}^{-1} \min ^{-1}\right)$ & 0.4051 & -0.0922 & & -1.4705 & -2.3101 & 0.2235 & 0.6637 & 0.2546 & 0.5264 & 0.1757 \\
\hline$Q_{\mathrm{eq}}(\mathrm{cal}).\left(\mathrm{mg} \mathrm{g}^{-1}\right)$ & 2.3833 & 1.7042 & & 2.4428 & 2.4549 & 2.3867 & 2.3820 & 2.2247 & 1.9309 & 2.3540 \\
\hline$R^{2}$ & 0.999 & 0.990 & & 0.999 & 0.999 & 0.997 & 0.998 & 0.999 & 0.999 & 0.996 \\
\hline \multicolumn{11}{|l|}{ Elovich } \\
\hline$a\left(\mathrm{mgg}^{-1} \mathrm{~min}^{-1}\right)$ & 2.1465 & 2.0601 & 4.1905 & 2.5142 & 2.5306 & 2.1624 & 2.2250 & 1.8690 & 1.7040 & 1.8696 \\
\hline$b\left(\mathrm{~g} \mathrm{mg}^{-1}\right)$ & 0.0454 & 0.0599 & -0.4842 & -0.0139 & -0.0153 & 0.0211 & 0.0211 & 0.0667 & 0.0474 & 0.1019 \\
\hline$R^{2}$ & 0.639 & 0.883 & 0.712 & 0.610 & 0.687 & 0.768 & 0.709 & 0.982 & 0.850 & 0.949 \\
\hline$Q_{\mathrm{eq}}$ (exp.) $\left(\mathrm{mgg}^{-1}\right)$ & 2.2896 & \multicolumn{2}{|c|}{1.9629} & 2.4556 & 2.4557 & 2.3010 & 2.3526 & 2.1296 & 1.8835 & 2.2273 \\
\hline
\end{tabular}

$K_{1}$ : constant of pseudo-first-order velocity; $Q_{e q}$ : adsorbate amounts retained by adsorbent mass in equilibrium; $K_{2}$ : constant pseudo-second-order velocity; $a$ : constant indicating chemisorption initial speed; $b$ : number of suitable sites for the adsorption of the surface related to the coverage extension and the activation energy of chemisorption; $R^{2}$ : coefficient of determination.

TABLE 7: Kinetic parameters inherent to the intraparticle diffusion model for the removal of the metals $\mathrm{Cd}(\mathrm{II}), \mathrm{Pb}(\mathrm{II})$, and $\mathrm{Cr}(\mathrm{III})$ by adsorbents $\mathrm{M} . \mathrm{H}_{2} \mathrm{O}_{2}, \mathrm{M} . \mathrm{H}_{2} \mathrm{SO}_{4}$, and $\mathrm{NaOH}$.

\begin{tabular}{|c|c|c|c|c|c|}
\hline \multirow{2}{*}{ Adsorbents } & \multirow{2}{*}{ Intraparticle diffusion } & \multicolumn{2}{|c|}{$\mathrm{Cd}(\mathrm{II})$} & \multirow{2}{*}{$\mathrm{Pb}(\mathrm{II})$} & \multirow{2}{*}{$\mathrm{Cr}(\mathrm{III})$} \\
\hline & & Line A & Line B & & \\
\hline \multirow{3}{*}{ M. $\mathrm{H}_{2} \mathrm{O}_{2}$} & $K_{\text {id }}\left(\mathrm{g} \mathrm{mg}^{-1} \mathrm{~min}^{-1 / 2}\right)$ & 0.0116 & & -0.0041 & 0.0183 \\
\hline & $C_{i}\left(\mathrm{mg} \mathrm{g}^{-1}\right)$ & 2.2346 & & 2.5030 & 1.9834 \\
\hline & $R^{2}$ & 0.5552 & & 0.6676 & 0.9082 \\
\hline \multirow{3}{*}{ M. $\mathrm{H}_{2} \mathrm{SO}_{4}$} & $K_{\text {id }}\left(\mathrm{g} \mathrm{mg}^{-1} \mathrm{~min}^{-1 / 2}\right)$ & 0.0284 & -0.0710 & 0.0086 & 0.0134 \\
\hline & $C_{i}\left(\mathrm{mg} \mathrm{g}^{-1}\right)$ & 2.1038 & 2.6272 & 2.1815 & 1.7690 \\
\hline & $R^{2}$ & 0.7800 & 0.6781 & 0.7094 & 0.9280 \\
\hline \multirow{3}{*}{ M. $\mathrm{NaOH}$} & $K_{\text {id }}\left(\mathrm{g} \mathrm{mg}^{-1} \mathrm{~min}^{-1 / 2}\right)$ & -0.0035 & & 0.0049 & 0.0323 \\
\hline & $C_{i}\left(\mathrm{mg} \mathrm{g}^{-1}\right)$ & 2.4865 & & 2.2744 & 1.9919 \\
\hline & $R^{2}$ & 0.5127 & & 0.6265 & 0.8472 \\
\hline
\end{tabular}

$K_{\mathrm{id}}$ : intraparticle diffusion constant; $C_{i}$ : suggesting the thickness of the boundary layer effect; $R^{2}$ : coefficient of determination.

TABle 8: Parameters related to the linear models for Langmuir and Freundlich adsorption of $\mathrm{Cd}(\mathrm{II}), \mathrm{Pb}(\mathrm{II})$, and $\mathrm{Cr}(\mathrm{III})$ by $\mathrm{M}$. $\mathrm{H}_{2} \mathrm{O}_{2}, \mathrm{M}$. $\mathrm{H}_{2} \mathrm{SO}_{4}$, and $\mathrm{M}$. $\mathrm{NaOH}$ materials.

\begin{tabular}{|c|c|c|c|c|c|c|c|c|c|c|}
\hline \multicolumn{2}{|c|}{ Parameters } & M. $\mathrm{H}_{2} \mathrm{O}_{2}$ & $\begin{array}{c}\text { M. } \mathrm{H}_{2} \mathrm{SO}_{4} \\
\mathrm{Cd}(\mathrm{II})\end{array}$ & M. NaOH & M. $\mathrm{H}_{2} \mathrm{O}_{2}$ & $\begin{array}{c}\text { M. } \mathrm{H}_{2} \mathrm{SO}_{4} \\
\mathrm{~Pb}(\mathrm{II})\end{array}$ & M. $\mathrm{NaOH}$ & M. $\mathrm{H}_{2} \mathrm{O}_{2}$ & $\begin{array}{c}\text { M. } \mathrm{H}_{2} \mathrm{SO}_{4} \\
\mathrm{Cr}(\mathrm{III})\end{array}$ & M. NaOH \\
\hline \multirow{4}{*}{ Langmuir } & $Q_{m}$ & 13.421 & 7.058 & 19.539 & 21.678 & 24.004 & 42.463 & 43.975 & 10.074 & 54.645 \\
\hline & $K_{L}$ & 0.026 & 0.017 & 0.006 & 0.022 & 0.019 & 0.002 & 0.013 & 0.049 & 0.010 \\
\hline & $R_{L}$ & 0.163 & 0.224 & 0.467 & 0.188 & 0.207 & 0.667 & 0.273 & 0.093 & 0.329 \\
\hline & $R^{2}$ & 0.993 & 0.980 & 0.996 & 0.994 & 0.938 & 0.996 & 0.990 & 0.964 & 0.870 \\
\hline \multirow{3}{*}{ Freundlich } & $K_{f}$ & 1.967 & 1.565 & 3.634 & 2.510 & 1.692 & 3.393 & 2.025 & 1.420 & 5.448 \\
\hline & $n$ & 2.287 & 1.020 & 1.678 & 1.764 & 1.488 & 0.762 & 2.700 & 3.031 & 3.580 \\
\hline & $R^{2}$ & 0.934 & 0.977 & 0.902 & 0.980 & 0.977 & 0.931 & 0.855 & 0.862 & 0.834 \\
\hline
\end{tabular}

$\mathrm{Q}_{m}\left(\mathrm{mgg}^{-1}\right)$ : maximum adsorption capacity; $K_{L}$ or $b\left(\mathrm{~L} \mathrm{mg}^{-1}\right)$ : constant related to the strength of adsorbent/adsorbate interaction; $R_{L}$ : Langmuir constant; $R^{2}$ : coefficient of determination; $K_{f}\left(\mathrm{mg} \mathrm{g}^{-1}\right)$ : related to the adsorption capacity; $n$ : related to the solid heterogeneity. 
TABLE 9: Thermodynamic parameters for modified adsorbents from cassava peels in the removal of $\mathrm{Cd}(\mathrm{II}), \mathrm{Pb}(\mathrm{II})$, and $\mathrm{Cr}(\mathrm{III})$.

\begin{tabular}{|c|c|c|c|c|c|c|c|c|c|c|c|c|c|c|c|c|}
\hline \multirow{2}{*}{ Adsorbents } & \multirow{2}{*}{ Temp. ${ }^{\circ} \mathrm{C}$} & \multicolumn{5}{|c|}{$\mathrm{Cd}(\mathrm{II})$} & \multicolumn{5}{|c|}{$\mathrm{Pb}(\mathrm{II})$} & \multicolumn{5}{|c|}{$\mathrm{Cr}(\mathrm{III})$} \\
\hline & & $Q_{\mathrm{eq}}$ & $\Delta G$ & $\Delta H$ & $\Delta S$ & $R^{2}$ & $Q_{\mathrm{eq}}$ & $\Delta G$ & $\Delta H$ & $\Delta S$ & $R^{2}$ & $Q_{\mathrm{eq}}$ & $\Delta G$ & $\Delta H$ & $\Delta S$ & $R^{2}$ \\
\hline \multirow{5}{*}{ M. $\mathrm{H}_{2} \mathrm{O}_{2}$} & 15 & 6.4 & 3.0 & \multirow{5}{*}{15.5} & \multirow{5}{*}{43.6} & \multirow{5}{*}{0.93} & 11.8 & -3.6 & \multirow{5}{*}{-59.5} & \multirow{5}{*}{-194.2} & \multirow{5}{*}{0.92} & 10.9 & -1.4 & \multirow{5}{*}{-5.7} & \multirow{5}{*}{-15.1} & \multirow{5}{*}{0.93} \\
\hline & 25 & 6.1 & 2.6 & & & & 10.7 & -1.7 & & & & 10.5 & -1.2 & & & \\
\hline & 35 & 7.8 & 2.1 & & & & 10.0 & 0.3 & & & & 10.7 & -1.1 & & & \\
\hline & 45 & 8.7 & 1.7 & & & & 10.5 & 2.2 & & & & 10.5 & -0.9 & & & \\
\hline & 55 & 9.0 & 1.3 & & & & 10.7 & 4.1 & & & & 10.1 & -0.8 & & & \\
\hline \multirow{5}{*}{ M. $\mathrm{H}_{2} \mathrm{SO}_{4}$} & 15 & 5.6 & 3.8 & \multirow{5}{*}{5.6} & \multirow{5}{*}{6.5} & \multirow{5}{*}{0.98} & 10.9 & -1.0 & \multirow{5}{*}{-59.6} & \multirow{5}{*}{-203.9} & \multirow{5}{*}{0.80} & 10.1 & -0.2 & \multirow{5}{*}{-9.9} & \multirow{5}{*}{-34.0} & \multirow{5}{*}{0.98} \\
\hline & 25 & 6.0 & 3.7 & & & & 7.7 & 1.1 & & & & 8.6 & 0.2 & & & \\
\hline & 35 & 6.3 & 3.7 & & & & 7.5 & 3.1 & & & & 9.2 & 0.5 & & & \\
\hline & 45 & 6.2 & 3.6 & & & & 8.6 & 5.2 & & & & 9.6 & 0.8 & & & \\
\hline & 55 & 6.9 & 3.5 & & & & 8.4 & 7.2 & & & & 8.8 & 1.2 & & & \\
\hline \multirow{5}{*}{ M. NaOH } & 15 & 12.5 & -5.2 & \multirow{5}{*}{-29.7} & \multirow{5}{*}{-85.2} & \multirow{5}{*}{0.87} & 11.8 & 21.5 & \multirow{5}{*}{-0.26} & \multirow{5}{*}{-75.5} & \multirow{5}{*}{0.89} & 11.6 & -3.2 & & & \\
\hline & 25 & 11.6 & -4.3 & & & & 11.7 & 22.2 & & & & 11.7 & -4.0 & & & \\
\hline & 35 & 11.5 & -3.5 & & & & 11.6 & 23.0 & & & & 11.7 & -4.7 & 18.1 & 74.1 & 0.87 \\
\hline & 45 & 11.9 & -2.6 & & & & 11.5 & 23.8 & & & & 11.9 & -5.4 & & & \\
\hline & 55 & 11.2 & -1.8 & & & & 11.7 & 24.5 & & & & 12.0 & -6.2 & & & \\
\hline
\end{tabular}

$\mathrm{Q}_{\mathrm{eq}}\left(\mathrm{mg} \mathrm{g}^{-1}\right) ; \Delta G\left(\mathrm{KJ} \mathrm{mol}^{-1}\right) ; \Delta H\left(\mathrm{KJ} \mathrm{mol}^{-1}\right) ; \Delta S\left(\mathrm{~J} \mathrm{~mol}^{-1} \mathrm{~K}^{-1}\right)$.

M. $\mathrm{H}_{2} \mathrm{SO}_{4}$ show a reduction of the amount adsorbed $\left(Q_{\mathrm{eq}}\right)$, with increasing system temperature.

In the case of other modified adsorbents, a great difference was observed in the amount of adsorbed metal versus system temperature. Other thermodynamic parameters shown in Table 9 will be discussed in the following sections.

\section{Discussion}

4.1. Characterization of Chemically Modified Adsorbents. Figure 1 shows that the modifier solution $\left(\mathrm{H}_{2} \mathrm{O}_{2}, \mathrm{H}_{2} \mathrm{SO}_{4}\right.$, and $\mathrm{NaOH})$ and stirring time and temperature $\left(65^{\circ} \mathrm{C}\right)$ caused changes in the superficial charge of the modified adsorbents since the $\mathrm{pH}_{\mathrm{PZC}}$ of the adsorbent was changed to lower or higher rates to $\mathrm{pH}_{\mathrm{PZC}}$ material in natura.

The adsorption of $\mathrm{Cd}(\mathrm{II}), \mathrm{Pb}(\mathrm{II})$, and $\mathrm{Cr}$ (III) ions would be favored by $\mathrm{pH}$ rates higher than $\mathrm{pH}_{\mathrm{PZC}}$, since in these cases, according to [31], the surface of the adsorbent has a predominance of negative charges.

Table 2 demonstrates the occurrence of changes in the chemical constitution of the biomass originated from cassava peels after treatment with solutions containing $0.1 \mathrm{~mol} \mathrm{~L}^{-1}$ $\mathrm{H}_{2} \mathrm{O}_{2}, \mathrm{H}_{2} \mathrm{SO}_{4}$, and $\mathrm{NaOH}$ for 6 hours at $200 \mathrm{rpm}$ and $60^{\circ} \mathrm{C}$. The chemical solutions removed great quantities of chemical elements in biomass in natura and caused changes in the chemical structure, resulting in modified adsorbents $\mathrm{M}$. $\mathrm{H}_{2} \mathrm{O}_{2}, \mathrm{M} . \mathrm{H}_{2} \mathrm{SO}_{4}$, and $\mathrm{M} . \mathrm{NaOH}$.

It may be noted that a consistent decrease in $\mathrm{K}, \mathrm{Ca}, \mathrm{Mg}$, and $\mathrm{Cu}$ concentrations (Table 2 ) in the chemical composition of biomass showed that solutions have been applied to produce effective modified chemical adsorbents.

The results (Figure 1 and Table 2) demonstrated that the simple washing of vegetable residual biomass with chemical agents, with energy added to the system $\left(60^{\circ} \mathrm{C}\right)$, was sufficiently capable of causing modifications in the biomass.
One may also note that these modifications are favorable or unfavorable to the adsorption process by further studies since the adsorption process tends to be specific for each adsorbent/adsorbate.

4.2. Preliminary Studies Involving $p H$ of the Adsorbent's Medium and Mass. A significant difference was found at $1 \%$ to the source of mass variation adsorbent for linear (L) and quadratic (Q) templates (Table 4), with regard to adsorbents M. in natura, $\mathrm{M} . \mathrm{H}_{2} \mathrm{O}_{2}, \mathrm{M} . \mathrm{H}_{2} \mathrm{SO}_{4}$, and $\mathrm{NaOH}$ for adsorption of $\mathrm{Cd}(\mathrm{II}), \mathrm{Pb}(\mathrm{II})$, and $\mathrm{Cr}(\mathrm{III})$.

Since no significant differences were found for the source of variation $\mathrm{pH}$, this fact indicated that the conditions on which the surveys were conducted at the $\mathrm{pH}$ range studied had no influence on the adsorption process, either to adsorbents in natura or to absorbents modified for the removal of $\mathrm{Cd}(\mathrm{II}), \mathrm{Pb}(\mathrm{II})$, and $\mathrm{Cr}$ (III).

This result indicates that each adsorbent when assessed separately for each metal presents significant difference as regards the mass of adsorbent that was used. From the obtained results, it was observed that lower adsorbent masses result in higher adsorption capacity.

When the response surfaces (Figure 2) and the resulting multivariable equations (Table 4) were evaluated, M. $\mathrm{NaOH}$ showed the highest removal rate of Cd(II) $1.95 \mathrm{mg} \mathrm{g}^{-1}$, approximately $8 \%$ higher than $\mathrm{M}$. in natura.

In the case of the removal of $\mathrm{Pb}(\mathrm{II})$, the modified adsorbents $\mathrm{M} . \mathrm{H}_{2} \mathrm{O}_{2}, \mathrm{M} . \mathrm{H}_{2} \mathrm{SO}_{4}$, and $\mathrm{M}$. $\mathrm{NaOH}$ showed equal or slightly higher average than $\mathrm{M}$. in natura adsorbent.

As for the removal of $\mathrm{Cr}(\mathrm{III}), \mathrm{M} . \mathrm{H}_{2} \mathrm{SO}_{4}$ modified adsorbent showed higher removal rate, adsorbing more than $12 \%$ of $\mathrm{M}$. in natura, reaching $1.60 \mathrm{mg} \mathrm{g}^{-1}$ in the preliminary test.

The studied $\mathrm{pH}$ range did not influence the adsorption process, which is an excellent result, because these modified 
adsorbents may be used in a wide $\mathrm{pH}$ range, such as contaminated waters or effluents containing metals, and still maintaining high efficiency removal of these metals.

4.3. Studies Involving Adsorption Kinetics. According to results (Figure 3 ), the sorption system is in chemical equilibrium after 40 minutes of stirring, with no great increments for adsorption of $\mathrm{Cd}(\mathrm{II}), \mathrm{Pb}(\mathrm{II})$, or $\mathrm{Cr}$ (III) by the adsorbents M. $\mathrm{H}_{2} \mathrm{O}_{2}, \mathrm{M} . \mathrm{H}_{2} \mathrm{SO}_{4}$, and $\mathrm{M}$. NaOH.

In the case of the kinetics models performed to results in Figure 3, good mathematical adjustments $\left(R^{2}\right)$ to the pseudosecond-order model were reported, satisfactorily applicable in all studied adsorbents $\left(\mathrm{M} . \mathrm{H}_{2} \mathrm{O}_{2}, \mathrm{M} . \mathrm{H}_{2} \mathrm{SO}_{4}\right.$, and $\mathrm{M}$. $\mathrm{NaOH}$ ) in removing $\mathrm{Cd}(\mathrm{II}), \mathrm{Pb}(\mathrm{II})$, and $\mathrm{Cr}$ (III). It must be emphasized that the $Q_{\mathrm{eq}}$ (calc.) rates obtained for the pseudosecond-order model are very close to the experimental ones $\left(Q_{\text {eq exp. }}\right)$ and demonstrated the excellent adjustment and precision [32] to estimate the chemically adsorbed amount of $\mathrm{Cd}(\mathrm{II}), \mathrm{Pb}(\mathrm{II})$, and $\mathrm{Cr}(\mathrm{III})$ [33].

However, the model of pseudo-first order did not provide satisfactory mathematical adjustments and failed to explain satisfactorily the sorption phenomenon observed. $K_{1}$ observed generally has negative values and indicates that the concentration of solute in the solution decreases with increasing time [34].

The pseudo-first- and pseudo-second-order models reveal that the difference between the concentration adsorbed at a given time and concentration adsorbed on equilibrium is the movement force for adsorption, and the overall adsorption rate, proportional to the movement force in the case of pseudo-first-order equation, is the square of movement force to the pseudo-second-order model. These models also indicate that the adsorption process is a "false" order chemical reaction, and adsorption rate may be determined by the reaction equations of the first-order and second-order reaction [23].

The values of $K_{2}$ obtaining angular coefficients of the line were $-0.0922,-1.4705$, and $-2.3101 \mathrm{~g} \mathrm{mg}^{-1} \mathrm{~min}^{-1}$ for $\mathrm{M}$. $\mathrm{H}_{2} \mathrm{SO}_{4}$ for adsorption of $\mathrm{Cd}(\mathrm{II}), \mathrm{M}$. NaOH for adsorption of $\mathrm{Cd}(\mathrm{II})$, and $\mathrm{M}$. $\mathrm{H}_{2} \mathrm{O}_{2}$ for adsorption of $\mathrm{Pb}(\mathrm{II})$, respectively. The negative values for $K_{2}$ suggest that the metal adsorbed quantity $\left(Q_{t}\right)$ decreases with increasing time [35].

The kinetics of the pseudo-second order describes chemical adsorption processes involving donating or electron exchange between the adsorbate and adsorbent, such as covalent and ionic exchange forces [20]; in this type of adsorption, the molecules are not attracted by the solid surface points, but specifically for the active centers, to form initially a single layer; then there may be the formation of other layers by physisorption.

The Elovich model showed good mathematical adjustment only for the adsorption of $\mathrm{Cr}$ (III) by $\mathrm{M}$. $\mathrm{H}_{2} \mathrm{SO}_{4}$. Results reveal that, for the adsorption of $\mathrm{Cr}$ (III) by $\mathrm{M}$. NaOH in the initial moments of the adsorption, chemisorption is predominant, as proposed by the Elovich's model.

Results in Table 7 demonstrate that the model predicts the intraparticle diffusion, or rather when there is a movement of the metal particle into the adsorbent pores, adequate mathematical adjustments were not provided, in a limiting step for adsorption of $\mathrm{Cd}(\mathrm{II}), \mathrm{Pb}(\mathrm{II})$, or $\mathrm{Cr}$ (III).

In a similar research, Schwantes et al. [36] evaluated $\mathrm{Cd}$ (II) adsorption kinetics by M. in natura and found better mathematical adjustments to the model of pseudo-second order. According to the authors, this result suggests chemical adsorption of the element by the adsorbent.

It should be noted that the kinetics of the pseudosecond order describes well the chemical adsorption processes involving donation or exchange of electrons between the adsorbate and the adsorbent as covalent forces and ion exchange [35].

4.4. Studies of Adsorption Isotherms. Results obtained in studies of adsorption equilibrium $\mathrm{Cd}(\mathrm{II}), \mathrm{Pb}(\mathrm{II})$, and $\mathrm{Cr}$ (III) by the base adsorbent-modified cassava peels were used to construct the adsorption isotherms. The results obtained were linearized by Langmuir's and Freundlich's mathematical models (Table 8).

Good adjustments to Langmuir's model were reported (Table 8), suggesting adsorption of monolayers of Cd(II) by M. $\mathrm{H}_{2} \mathrm{O}_{2}, \mathrm{M} . \mathrm{H}_{2} \mathrm{SO}_{4}$, and $\mathrm{M}$. $\mathrm{NaOH}, \mathrm{Pb}$ (II) by M. NaOH and $\mathrm{M} . \mathrm{H}_{2} \mathrm{O}_{2}$, and $\mathrm{Cr}$ (III) by $\mathrm{M} . \mathrm{H}_{2} \mathrm{O}_{2}$ and $\mathrm{M} . \mathrm{H}_{2} \mathrm{SO}_{4}$. It should be underscored that the adsorbent $\mathrm{M}$. $\mathrm{NaOH}$ provided the highest removal capacity of $\mathrm{Cd}$ (II) $19.5 \mathrm{mg} \mathrm{g}^{-1}$, when compared to $7.0 \mathrm{mg} \mathrm{g}^{-1}$ and $13.4 \mathrm{mg} \mathrm{g}^{-1}$ of adsorbents $\mathrm{M}$. $\mathrm{H}_{2} \mathrm{O}_{2}$ and $\mathrm{M} . \mathrm{H}_{2} \mathrm{SO}_{4}$.

Higher rates were detected for $\mathrm{M}$. NaOH adsorbent in removing $\mathrm{Pb}(\mathrm{II})$, with $Q_{m}$ at $42.5 \mathrm{mgg}^{-1}, 1.45$ times the removal reported by Schwantes et al. [36] in a similar experiment, where $Q_{m}$ with $29.26 \mathrm{mg} \mathrm{g}^{-1}$ for M. in natura was obtained.

Regarding the removal of Cr(III), the high adsorption capacity of $\mathrm{M} . \mathrm{H}_{2} \mathrm{O}_{2}$ material should be emphasized, or rather $43.9 \mathrm{mgg}^{-1}$ to $Q_{m}$, which is 15 times higher than results by Schwantes et al. [2] to evaluate the use of $\mathrm{M}$. in natura materials removing the $\operatorname{Cr}(\mathrm{III})$ with $Q_{m}$ of $2.85 \mathrm{mg} \mathrm{g}^{-1}$. The result is remarkable since the adsorbent $\mathrm{M} . \mathrm{H}_{2} \mathrm{O}_{2}$ increased sorption capacity by 15 times with only minor chemical modifications, especially in the case of the trivalent ion $\mathrm{Cr}$ (III), which required 3 positive active sites on the adsorbent.

However, Table 8 shows that modified adsorbents exhibited high $Q_{m}$ rates, but lower $K_{L}$ rates are observed. The above indicated that the strength of the interaction between adsorbent and adsorbate was not enough for any of the metals studied.

In the adsorption of $\mathrm{Cr}$ (III), the modified adsorbents revealed lower rates for $K_{L}$, though some studies have shown that activated carbon, an excellent adsorbent for most pollutants, may also have a low interaction to adsorbent/adsorbate $\left(K_{L}\right)$, as Schwantes et al. [2] with $K_{L}$ rate of $0.010 \mathrm{~L} \mathrm{mg}^{-1}$ and Rubio et al. [37] with $K_{L}$ rate of $0.094 \mathrm{~L} \mathrm{mg}^{-1}$ showed.

It should also be noted that the adsorption procedure laid down by Langmuir's model was favorable due to $R_{L}$ rates between 0 and 1 [38].

In some cases, adsorption seems to occur in single and multilayer, as shown in Table 8. Good fits to Langmuir's and Freundlich's models have been reported for the adsorption of 
$\mathrm{Cd}$ (II) by the adsorbent $\mathrm{M} \mathrm{H}_{2} \mathrm{SO}_{4}$ and adsorption of $\mathrm{Pb}(\mathrm{II})$ by $\mathrm{M}$. $\mathrm{H}_{2} \mathrm{O}_{2}$.

Nacke et al. [39] report that research on the adsorption of metals by in natura Jatropha biomass obtained good adjustment $\left(R^{2}\right)$ for both models and suggested the occurrence of mono- or multilayer adsorption, as has been reported for the adsorption of $\mathrm{Cr}$ (III) by adsorbent $\mathrm{M} . \mathrm{H}_{2} \mathrm{O}_{2}$ in current study.

Fine adjustments to Freundlich's model were obtained, suggesting multilayer adsorption of $\mathrm{Cd}(\mathrm{II})$ by $\mathrm{M} . \mathrm{H}_{2} \mathrm{SO}_{4}$, $\mathrm{Pb}$ (II) by $\mathrm{M} . \mathrm{H}_{2} \mathrm{O}_{2}$, and $\mathrm{M} . \mathrm{H}_{2} \mathrm{SO}_{4}$. In the cases above, Freundlich's rate of $n>1$ is a strong indication of high reactivity of the active sites of the adsorbent [40] and indicates modified adsorbents recommended for the removal of $\mathrm{Cd}(\mathrm{II})$ and $\mathrm{Pb}(\mathrm{II})$.

When $K_{f}$ rates were compared, $\mathrm{M} . \mathrm{H}_{2} \mathrm{SO}_{4}$ adsorbent obtained $1.56 \mathrm{mg} \mathrm{g}^{-1}$, or rather 2.6 times higher than that obtained by Rubio et al. [41] with $K_{f}$ rate of $0.582 \mathrm{mg} \mathrm{g}^{-1}$ for the removal of $\mathrm{Cd}$ (II) using crambe pie in natura.

In the case of the adsorbent $\mathrm{M} . \mathrm{H}_{2} \mathrm{O}_{2}$ for removal of $\mathrm{Pb}(\mathrm{II}) K_{f}$ values of $2.51 \mathrm{mg} \mathrm{g}^{-1}$ higher than other adsorbents such as in natura crambe pie [41] with $K_{f}=2.03 \mathrm{mg} \mathrm{g}^{-1}$, biosorbent of Saccharomyces [42] with $K_{f}=0.03 \mathrm{mg} \mathrm{g}^{-1}$, and even activated carbon synthesized of melon rinds [43] with $K_{f}=0.026$ the $0.015 \mathrm{mgg}^{-1}$ were obtained. These results demonstrate that the chemical modifications which resulted in the adsorbent $\mathrm{M} . \mathrm{H}_{2} \mathrm{O}_{2}$ were effective, providing a favorable multilayer adsorption of $\mathrm{Pb}$ (II).

4.5. Effect of Temperature on the Adsorption Process. Studies were conducted to evaluate the influence of temperature on modified adsorbents and their relationship in removing $\mathrm{Cd}(\mathrm{II}), \mathrm{Pb}(\mathrm{II})$, and $\mathrm{Cr}(\mathrm{III})$. However, it must be underscored that research determined the best temperature for the removal of metals, and that this too would raise operating costs [44], which is impractical. Consequently, the studies aimed at producing information on the thermodynamic nature of the sorption process through $\Delta G, \Delta H$, and $\Delta S$ parameters.

$\Delta H$ rates indicate endothermic $(\Delta H>0)$ or exothermic $(\Delta H<0)$ reaction systems [45]. Results in Table 9 show that the adsorption of $\mathrm{Cd}(\mathrm{II})$ by $\mathrm{M} . \mathrm{H}_{2} \mathrm{O}_{2}$ and $\mathrm{M} . \mathrm{H}_{2} \mathrm{SO}_{4}$ and the adsorption of $\mathrm{Cr}(\mathrm{III})$ by $\mathrm{M} . \mathrm{NaOH}$ are endothermic. On the other hand, the adsorption of $\mathrm{Cd}$ (II) by $\mathrm{M}$. $\mathrm{NaOH}$, the removal of $\mathrm{Pb}$ (II) by $\mathrm{M} . \mathrm{H}_{2} \mathrm{O}_{2}, \mathrm{M} \mathrm{H}_{2} \mathrm{SO}_{4}$, and $\mathrm{NaOH}$, and the adsorption of $\mathrm{Cr}(\mathrm{III})$ by M. $\mathrm{H}_{2} \mathrm{O}_{2}$ and $\mathrm{M}$. $\mathrm{H}_{2} \mathrm{SO}_{4}$ are exothermic processes, according to the negative rates by $\Delta H$.

According to Wan Ngah and Hanafiah [8], when $\Delta G$ has negative rates, it indicates the spontaneous nature of the reaction, while positive rates for $\Delta S$ indicate an increase in disorder and randomness of solid/solution interface during the sorption process.

Consequently, Table 9 reveals that the adsorption of $\mathrm{Cd}$ (II) by M. $\mathrm{H}_{2} \mathrm{SO}_{4}$ and $\mathrm{M} . \mathrm{H}_{2} \mathrm{O}_{2}$ and the removal of $\mathrm{Pb}(\mathrm{II})$ by $\mathrm{M}$. $\mathrm{NaOH}$ are not constituted by the spontaneous sorption process, while the adsorption of $\mathrm{Cd}(\mathrm{II})$ by $\mathrm{M}$. $\mathrm{NaOH}$ and the adsorption of $\mathrm{Cr}(\mathrm{III})$ by $\mathrm{M} . \mathrm{H}_{2} \mathrm{O}_{2}$ and $\mathrm{M}$. $\mathrm{NaOH}$ constitute spontaneous adsorptive processes due to negative rates by $\Delta G$.
It is worth mentioning that the sorption process may become spontaneous or not depending on the temperature of the medium, such as $\mathrm{Pb}$ (II) adsorption by $\mathrm{M} \mathrm{H}_{2} \mathrm{O}_{2}$ and $\mathrm{M}$. $\mathrm{H}_{2} \mathrm{SO}_{4}$, or in the removal of $\mathrm{Cr}$ (III) by $\mathrm{M}_{2} \mathrm{H}_{2} \mathrm{SO}_{4}$. In these cases, $\Delta G$ shows negative rates due to lower temperatures and does not tend towards spontaneity of the system with increasing temperature.

According to Wan Ngah and Fatinathan [45], positive rates of $\Delta S$ indicate increased randomness disorder and the solid/solution interface during the adsorption process, as occurred in the removal of Cd(II) by $\mathrm{M}_{2} \mathrm{H}_{2} \mathrm{O}_{2}, \mathrm{M} . \mathrm{H}_{2} \mathrm{SO}_{4}$, and $\mathrm{Cr}(\mathrm{III})$ by $\mathrm{M}$. $\mathrm{NaOH}$.

4.6. Acid Elution for Adsorbents Reuse. The elution in an acid solution demonstrates that the modified adsorbents show significant desorption of $\mathrm{Cd}(\mathrm{II})$ and $\mathrm{Pb}(\mathrm{II})$, allowing its reuse in new adsorption process. Modified adsorbents had the following values for desorption percentage of $\mathrm{Cd}(\mathrm{II})$ : $\mathrm{M}$. $\mathrm{H}_{2} \mathrm{O}_{2}(60 \%), \mathrm{M} . \mathrm{H}_{2} \mathrm{SO}_{4}(62 \%), \mathrm{M} . \mathrm{NaOH}$ (74\%), and $\mathrm{M}$. in natura (63\%); and they had the following percentages of desorption of $\mathrm{Pb}(\mathrm{II}): \mathrm{M} . \mathrm{H}_{2} \mathrm{O}_{2}$ (65\%), $\mathrm{M} . \mathrm{H}_{2} \mathrm{SO}_{4}$ (53\%), $\mathrm{M}$. $\mathrm{NaOH}(56 \%)$, and $\mathrm{M}$. in natura (77\%) [36]. The modified and $\mathrm{M}$. in natura [2] adsorbents showed no desorption of $\mathrm{Cr}(\mathrm{III})$ greater than $3 \%$, even in acid solution $0.1 \mathrm{~mol} / \mathrm{L} \mathrm{HCl}$, suggesting a strong ligation with this metal with biomass by chemical bounds.

\section{Conclusion}

The use of modifying agents in cassava peels is an alternative for the production of adsorbents with high metal adsorption capacity $(\mathrm{Cd}, \mathrm{Pb}$, and $\mathrm{Cr})$ without burdening the final product.

Results suggest that, in general, the chemisorption of metals $(\mathrm{Cd}, \mathrm{Pb}$, and $\mathrm{Cr})$ occurs in monolayer or multilayer or, in some cases, simultaneously.

The modified adsorbents presented better results when compared to the use of $\mathrm{M}$. in natura (biosorbent), with increase of $45 \%$ in $\mathrm{Pb}(\mathrm{II})$ adsorption by $\mathrm{M}$. $\mathrm{NaOH}$ and the increase of $1500 \%$ of $\mathrm{Cr}(\mathrm{III})$ by the use of $\mathrm{M}$. $\mathrm{H}_{2} \mathrm{O}_{2}$.

The use of solid waste (cassava peels) as raw material for modified adsorbents production is a relevant alternative for disposal of this waste and even enables added value to waste which is normally disposed of.

\section{Competing Interests}

The authors declare that they have no conflict of interests.

\section{Acknowledgments}

The authors would like to thank the CNPq for its funding and research productivity. Thanks are also due to CAPES for postgraduate fellowships and for undergraduate research.

\section{References}

[1] R. de Paula Lana, "Rational use of non renewable natural resources: biological, economical and environmental aspects," Brazilian Journal of Animal Science, vol. 38, pp. 330-340, 2009. 
[2] D. Schwantes, A. C. Gonçalves Jr., J. Casarin, A. Pinheiro, I. G. Pinheiro, and G. F. Coelho, "Removal of Cr (III) from contaminated water using industrial waste of the cassava as natural adsorbents," African Journal of Agriculture Research, vol. 10, no. 46, pp. 4241-4251, 2015.

[3] A. C. Jr. Gonçalves, H. Nacke, D. Schwantes, and G. F. Coelho, "Heavy metal contamination in brazilian agricultural soils due to application of fertilizers," in Environmental Risk Assessment of Soil Contamination, M. C. Hernández-Soriano, Ed., vol. 4, pp. 105-135, InTech, Rijeka, Croatia, 1st edition, 2014.

[4] B. Balci, O. Keskinkan, and M. Avci, "Use of BDST and an ANN model for prediction of dye adsorption efficiency of Eucalyptus camaldulensis barks in fixed-bed system," Expert Systems with Applications, vol. 38, no. 1, pp. 949-956, 2011.

[5] S.-H. Lin and R.-S. Juang, "Adsorption of phenol and its derivatives from water using synthetic resins and low-cost natural adsorbents: a review," Journal of Environmental Management, vol. 90, no. 3, pp. 1336-1349, 2009.

[6] B. H. S. Santiago, G. H. C. França, R. Fernades, and P. V. P. Selvam, "Study preliminary technical and economic feasibility for charcoal production in Brazil from coconut waste: a comparative study of production scenarios," Analytica, vol. 17, pp. 52-55, 2005.

[7] T.-C. Hsu, "Experimental assessment of adsorption of $\mathrm{Cu}^{2+}$ and $\mathrm{Ni}^{2+}$ from aqueous solution by oyster shell powder," Journal of Hazardous Materials, vol. 171, no. 1-3, pp. 995-1000, 2009.

[8] W. S. W. Wan Ngah and M. A. K. M. Hanafiah, "Removal of heavy metal ions from wastewater by chemically modified plant wastes as adsorbents: a review," Bioresource Technology, vol. 99, no. 10, pp. 3935-3948, 2008.

[9] G. F. Coelho, A. C. Gonçalves Jr., D. Schwantes, A. J. Miola, P. Y. R. Suzaki, and M. G. Dos Santos, "Modification of Pinus elliotti with hydrogen peroxide in removal of $\mathrm{Cd}(\mathrm{II})$ from aqueous solution," Revista SimREA, vol. 2, no. 1, pp. 52-56, 2014.

[10] V. C. G. Dos Santos, J. V. T. M. De Souza, C. R. T. Tarley, J. Caetano, and D. C. Dragunski, "Copper ions adsorption from aqueous medium using the biosorbent sugarcane Bagasse In Natura and chemically modified," Water, Air, and Soil Pollution, vol. 216, no. 1-4, pp. 351-359, 2011.

[11] A. J. Miola, A. C. Gonçalves Jr., D. Schwantes, G. F. Coelho, R. Braga, and M. G. Dos Santos, "Use of modified adsorbent with $\mathrm{NaOH}$ originated from Pinus elliotti in the removal of Cd(II) from contaminated waters," Revista SimREA, vol. 2, no. 1, pp. $1-5,2014$.

[12] D. Schwantes Jr., A. C. Gonçalves Jr., G. F. Coelho, H. Nacke, R. F. Braga, and A. J. Miola, "Pinus bark biosorbent (Pinus elliottii) modified with $\mathrm{H}_{2} \mathrm{SO}_{4}$ aiming the removal of $\mathrm{Cd}(\mathrm{II})$," Revista SimREA, vol. 2, no. 1, pp. 38-41, 2014.

[13] V. C. G. Dos Santos, C. R. T. Tarley, J. Caetano, and D. C. Dragunski, "Assessment of chemically modified sugarcane bagasse for lead adsorption from aqueous medium," Water Science \& Technology, vol. 62, no. 2, pp. 457-465, 2010.

[14] M. E. Argun and S. Dursun, "Removal of heavy metal ions using chemically modified adsorbents," Journal of International Environmental Application \& Science, vol. 1, no. 1-2, pp. 27-40, 2006.

[15] AOAC, Official Methods of Analysis, AOAC, Rockville, Md, USA, 18th edition, 2005.

[16] B. Welz and M. Sperling, Atomic Absorption Spectrometry, Wiley-VCH, Weinheim, Germany, 2nd edition, 1999.

[17] A. M. S. Mimura, T. V. De Almeida Vieira, P. B. Martelli, and H. De Fátima Gorgulho, "Utilization of rice husk to remove $\mathrm{Cu}^{2+}$,
$\mathrm{Al}^{3+}, \mathrm{Ni}^{2+}$ and $\mathrm{Zn}^{2+}$ from wastewater," Química Nova, vol. 33, no. 6, pp. 1279-1284, 2010.

[18] N. B. Barros, R. E. Bruns, and I. S. Scarminio, How Do Experiments-Applications in Science and Industry, Bookman, 4th edition, 2010.

[19] Z. Aksu, "Equilibrium and kinetic modelling of cadmium(II) biosorption by $C$. vulgaris in a batch system: effect of temperature," Separation and Purification Technology, vol. 21, no. 3, pp. 285-294, 2001.

[20] Y. S. Ho and G. McKay, "Pseudo-second order model for sorption processes," Process Biochemistry, vol. 34, no. 5, pp. 451465, 1999.

[21] Y. S. Ho and G. McKay, "Sorption of copper(II) from aqueous solution by peat," Water, Air, and Soil Pollution, vol. 158, no. 1, pp. 77-97, 2004.

[22] A. Witek-Krowiak, R. G. Szafran, and S. Modelski, "Biosorption of heavy metals from aqueous solutions onto peanut shell as a low-cost biosorbent," Desalination, vol. 265, no. 1-3, pp. 126-134, 2011.

[23] X. Yang and B. Al-Duri, "Kinetic modeling of liquid-phase adsorption of reactive dyes on activated carbon," Journal of Colloid and Interface Science, vol. 287, no. 1, pp. 25-34, 2005.

[24] R. Han, L. Zhang, C. Song, M. Zhang, H. Zhu, and L. Zhang, "Characterization of modified wheat straw, kinetic and equilibrium study about copper ion and methylene blue adsorption in batch mode," Carbohydrate Polymers, vol. 79, no. 4, pp. 1140$1149,2010$.

[25] V. O. Njoku, E. E. Oguzie, C. Obi, O. S. Bello, and A. A. Ayuk, "Adsorption of copper(II) and lead(II) from aqueous solutions onto a Nigerian natural clay," Australian Journal of Basic and Applied Sciences, vol. 5, no. 5, pp. 346-353, 2011.

[26] K. R. Hall, L. C. Eagleton, A. Acrivos, and T. Vermeulen, "Pore- and solid-diffusion kinetics in fixed-bed adsorption under constant-pattern conditions," Industrial \& Engineering Chemistry Fundamentals, vol. 5, no. 2, pp. 212-223, 1966.

[27] Z. Aksu and I. A. İşoğlu, "Removal of copper(II) ions from aqueous solution by biosorption onto agricultural waste sugar beet pulp," Process Biochemistry, vol. 40, no. 9, pp. 3031-3044, 2005.

[28] A. Sari, M. Tuzen, D. Citak, and M. Soylak, "Equilibrium, kinetic and thermodynamic studies of adsorption of $\mathrm{Pb}(\mathrm{II})$ from aqueous solution onto Turkish kaolinite clay," Journal of Hazardous Materials, vol. 149, no. 2, pp. 283-291, 2007.

[29] M. Gonçalves, L. C. A. Oliveira, and M. C. Guerreiro, "Magnetic niobia as adsorbent of organic contaminants in aqueous medium: effect of temperature and pH," Química Nova, vol. 31, no. 3, pp. 518-522, 2008.

[30] F. Rubio, A. C. Gonçalves Jr., D. C. Dragunski, C. R. T. Tarley, A. P. Meneghel, and D. Schwantes, "A Crambe abyssinica seed by-product as biosorbent for lead(II) removal from water," Desalination and Water Treatment, vol. 53, no. 1, pp. 139-148, 2015.

[31] G. V. Tagliaferro, P. H. F. Pereira, L. Á. Rodrigues, and M. L. C. Pinto Da Silva, "Cadmium, lead and silver adsorptio in hydrous niobium oxide prepared by homogeneous solution method," Química Nova, vol. 34, no. 1, pp. 101-105, 2011.

[32] J. Febrianto, A. N. Kosasih, J. Sunarso, Y.-H. Ju, N. Indraswati, and S. Ismadji, "Equilibrium and kinetic studies in adsorption of heavy metals using biosorbent: a summary of recent studies," Journal of Hazardous Materials, vol. 162, no. 2-3, pp. 616-645, 2009. 
[33] U. Farooq, M. A. Khan, M. Athar, and J. A. Kozinski, "Effect of modification of environmentally friendly biosorbent wheat (Triticum aestivum) on the biosorptive removal of cadmium(II) ions from aqueous solution," Chemical Engineering Journal, vol. 171, no. 2, pp. 400-410, 2011.

[34] E. E. Baldez, N. F. Robaina, and R. J. Cassella, "Employment of polyurethane foam for the adsorption of Methylene Blue in aqueous medium," Journal of Hazardous Materials, vol. 159, no. 2-3, pp. 580-586, 2008.

[35] J. J. S. Neta, C. J. Silva, G. M. Moreira, C. Reis, and E. L. Reis, "Removal of the reactive blue 21 and direct red 80 dyes using seed residue of Mabea fistulifera Mart. as biosorbent," Revista Ambiente \& Água, vol. 7, no. 1, 2012.

[36] D. Schwantes, A. C. Gonçalves Jr., L. Strey, V. Schwantes, and H. Nacke, "Kinetics, equilibrium and thermodynamics of the adsorption process of lead using cassava industry wastes," in Green Design, Materials and Manufacturing Process, H. M. Bártolo, P. J. da Silva Bártolo, N. M. F. Alves et al., Eds., pp. 417422, CRC Press Taylor \& Francis Grou, Boca Raton, Fla, USA, 1st edition, 2013.

[37] F. Rubio, A. C. Gonçalves Jr., L. Strey, A. P. Meneghel, G. F. Coelho, and H. Nacke, "Applicability of Crambe abyssinica Hochst. Byproduct as biosorbent in the removal of chromium from water," Spanish Journal of Rural Development, vol. 4, no. 1, pp. 25-40, 2013.

[38] K. G. Bhattacharyya and A. Sarma, "Adsorption characteristics of the dye, Brilliant Green, on Neem leaf powder," Dyes and Pigments, vol. 57, no. 3, pp. 211-222, 2003.

[39] H. Nacke, A. C. Gonçalves Jr., G. F. Coelho, L. Strey, and A. Laufer, "Renewable energy technologies: removal of cadmium from aqueous solutions by adsorption on Jatropha biomass," in Green Design, Materials and Manufacturing Processes, $\mathrm{H}$. Bártolo and J. P. Duarte, Eds., pp. 367-372, CRC Press Taylor \& Francis Group, Boca Raton, Fla, USA, 1st edition, 2013.

[40] A. C. Gonçalves Jr., L. Strey, C. A. Lindino, H. Nacke, D. Schwantes, and E. P. Seidel, "Applicability of the pinus bark (Pinus elliottii) for the adsorption of toxic heavy metals from aqueous solutions," Acta Scientiarum: Technology, vol. 34, no. 1, pp. 79-87, 2012.

[41] F. Rubio, A. C. Gonçalves Jr., A. P. Meneghel, C. R. Teixeira Tarley, D. Schwantes, and G. F. Coelho, "Removal of cadmium from water using by-product Crambe abyssinica Hochst seeds as biosorbent material," Water Science and Technology, vol. 68, no. 1, pp. 227-233, 2013

[42] J. M. Ferreira, F. L. H. Da Silva, O. L. S. Alsina, L. D. S. C. Oliveira, E. B. Cavalcanti, and W. C. Gomes, "Equilibrium and kinetic study of $\mathrm{Pb}^{2+}$ biosorption by Saccharomyces cerevisiae," Química Nova, vol. 30, no. 5, pp. 1188-1193, 2007.

[43] J. J. Moreno-Barbosa, C. López-Velandia, A. D. P. Maldonado, L. Giraldo, and J. C. Moreno-Piraján, "Removal of lead(II) and zinc(II) ions from aqueous solutions by adsorption onto activated carbon synthesized from watermelon shell and walnut shell," Adsorption, vol. 19, no. 2, pp. 675-685, 2013.

[44] G. Crini and P.-M. Badot, "Application of chitosan, a natural aminopolysaccharide, for dye removal from aqueous solutions by adsorption processes using batch studies: a review of recent literature," Progress in Polymer Science, vol. 33, no. 4, pp. 399447, 2008.

[45] W. S. Wan Ngah and S. Fatinathan, "Adsorption characterization of $\mathrm{Pb}(\mathrm{II})$ and $\mathrm{Cu}(\mathrm{II})$ ions onto chitosan-tripolyphosphate beads: kinetic, equilibrium and thermodynamic studies," Journal of Environmental Management, vol. 91, no. 4, pp. 958-969, 2010. 

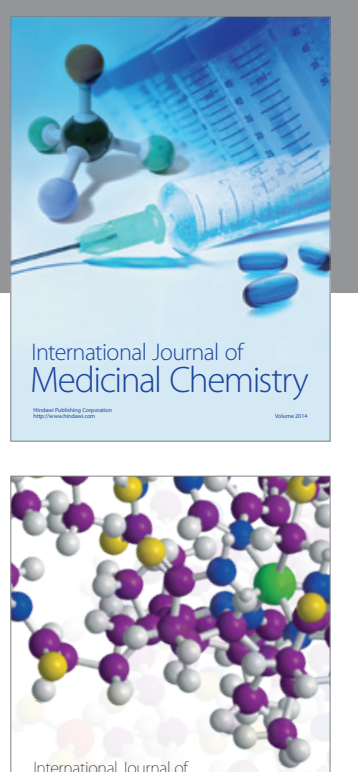

Carbohydrate Chemistry

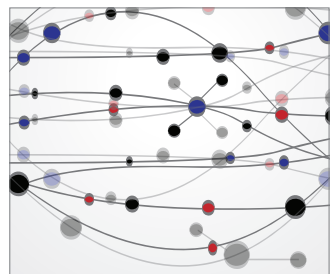

The Scientific World Journal
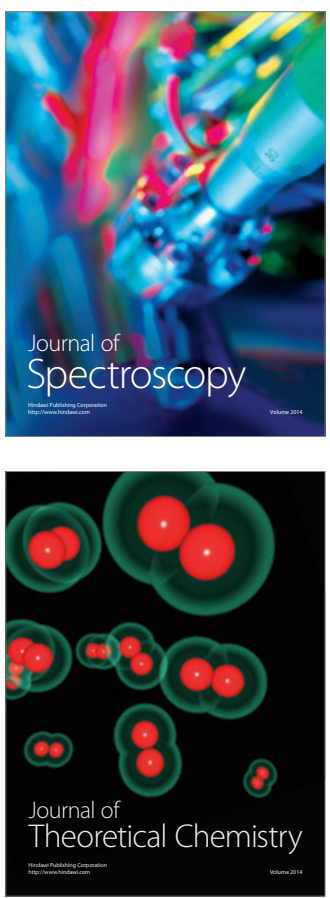
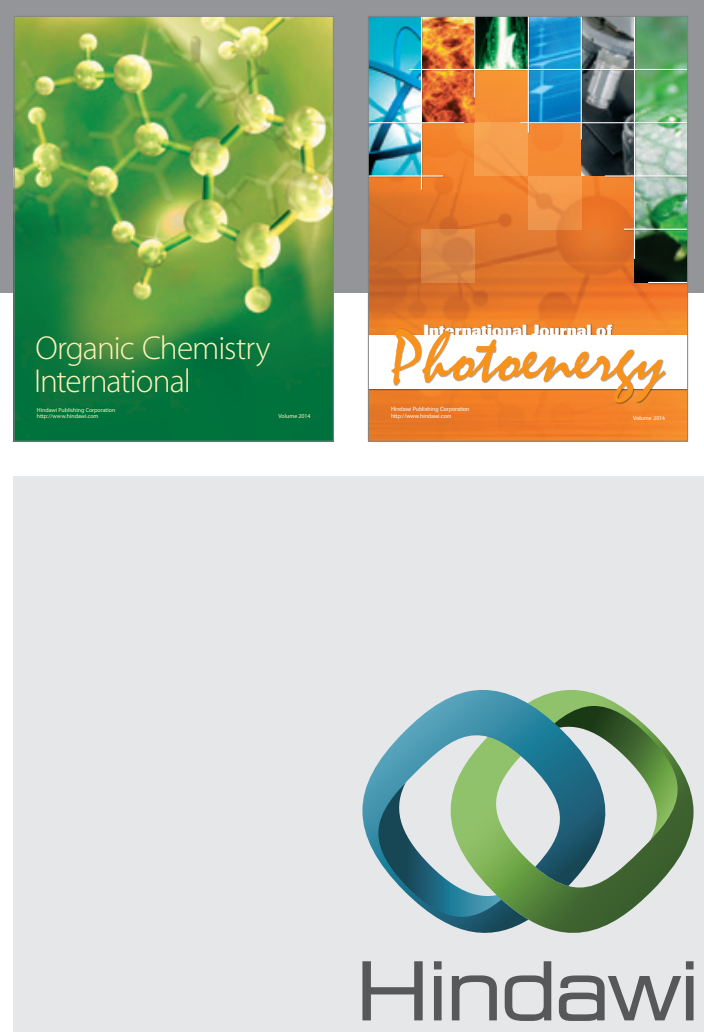

Submit your manuscripts at

http://www.hindawi.com

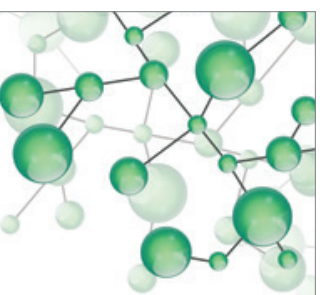

International Journal of

Inorganic Chemistry

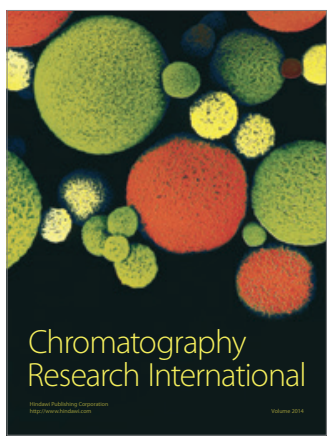

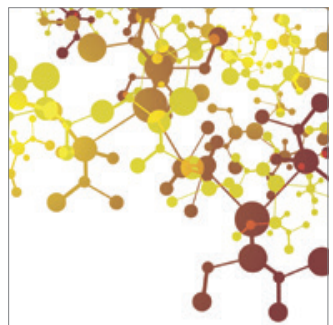

Applied Chemistry
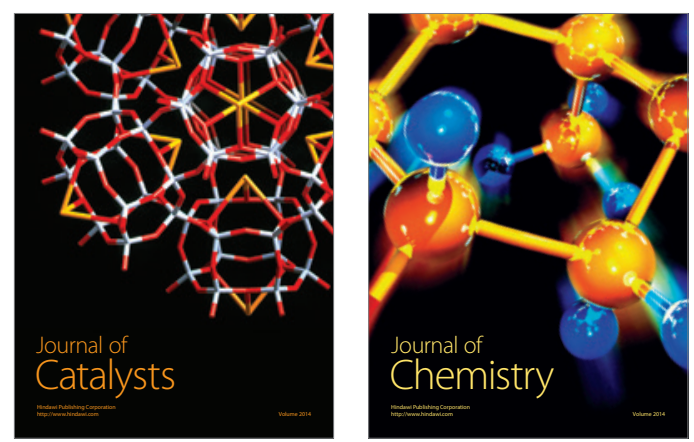
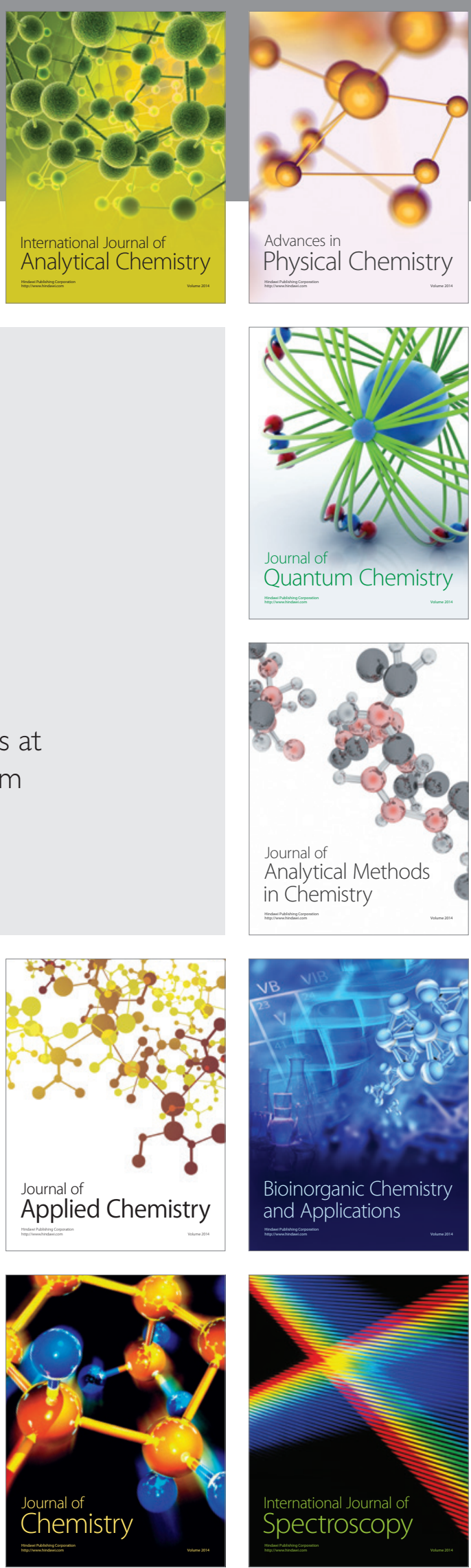